\title{
Retinal Amino Acid Neurochemistry of the Southern Hemisphere Lamprey, Geotria australis
}

\author{
Lisa Nivison-Smith ${ }^{1}$, Shaun P. Collin ${ }^{2,3,4}$, Yuan Zhu ${ }^{1}$, Sarah Ready ${ }^{5}$, Monica L. Acosta ${ }^{5}$, David M. Hunt ${ }^{2}$, \\ Ian C. Potter ${ }^{6}$, Michael Kalloniatis ${ }^{1,5,7 *}$
}

1 School of Optometry and Vision Science, University of New South Wales, Sydney, New South Wales, Australia, 2 School of Animal Biology and the University of Western Australia Oceans Institute, University of Western Australia, Crawley, Western Australia, Australia, 3 School of Biomedical Sciences, The University of Queensland, Brisbane, Queensland, Australia, 4 Queensland Brain Institute, University of Queensland, Brisbane, Queensland, Australia, 5 Department of Optometry and Vision Science, University of Auckland, Auckland, New Zealand, $\mathbf{6}$ School of Biological Sciences and Biotechnology, Murdoch University, Murdoch, Western Australia, Australia, 7 Centre for Eye Health, University of New South Wales, Sydney, New South Wales, Australia

\begin{abstract}
Lampreys are one of the two surviving groups of the agnathan (jawless) stages in vertebrate evolution and are thus ideal candidates for elucidating the evolution of visual systems. This study investigated the retinal amino acid neurochemistry of the southern hemisphere lamprey Geotria australis during the downstream migration of the young, recentlymetamorphosed juveniles to the sea and during the upstream migration of the fully-grown and sexually-maturing adults to their spawning areas. Glutamate and taurine were distributed throughout the retina, whilst GABA and glycine were confined to neurons of the inner retina matching patterns seen in most other vertebrates. Glutamine and aspartate immunoreactivity was closely matched to Müller cell morphology. Between the migratory phases, few differences were observed in the distribution of major neurotransmitters i.e. glutamate, GABA and glycine, but changes in amino acids associated with retinal metabolism i.e. glutamine and aspartate, were evident. Taurine immunoreactivity was mostly conserved between migrant stages, consistent with its role in primary cell functions such as osmoregulation. Further investigation of glutamate signalling using the probe agmatine (AGB) to map cation channel permeability revealed entry of AGB into photoreceptors and horizontal cells followed by accumulation in inner retinal neurons. Similarities in AGB profiles between upstream and downstream migrant of $G$. australis confirmed the conservation of glutamate neurotransmission. Finally, calcium binding proteins, calbindin and calretinin were localized to the inner retina whilst recoverin was localized to photoreceptors. Overall, conservation of major amino acid neurotransmitters and calcium-associated proteins in the lamprey retina confirms these elements as essential features of the vertebrate visual system. On the other hand, metabolic elements of the retina such as neurotransmitter precursor amino acids and Müller cells are more sensitive to environmental changes associated with migration.
\end{abstract}

Citation: Nivison-Smith L, Collin SP, Zhu Y, Ready S, Acosta ML, et al. (2013) Retinal Amino Acid Neurochemistry of the Southern Hemisphere Lamprey, Geotria australis. PLoS ONE 8(3): e58406. doi:10.1371/journal.pone.0058406

Editor: Steven Barnes, Dalhousie University, Canada

Received October 21, 2012; Accepted February 4, 2013; Published March 13, 2013

Copyright: (c) 2013 Nivison-Smith et al. This is an open-access article distributed under the terms of the Creative Commons Attribution License, which permits unrestricted use, distribution, and reproduction in any medium, provided the original author and source are credited.

Funding: This work was supported in part by research grants from the National Health and Medical Research Council of Australia National Health and Medical Research Council of Australia (number 1009342), the Australian Research Council and The WA State Government. The funders had no role in study design, data collection and analysis, decision to publish, or preparation of the manuscript.

Competing Interests: The authors have declared that no competing interests exist.

* E-mail: m.kalloniatis@unsw.edu.au

\section{Introduction}

Lampreys, together with the hagfishes, are the sole survivors of the early agnathan (jawless) stages in vertebrate evolution [1,2]. The fully differentiated lamprey eye possesses many similar features to the human eye including extra-ocular muscles, a multifocal lens and optic nerve [3-7]. The lamprey retina conforms to the common structure and composition observed in most vertebrate eyes [8]. Neurons are organised into discrete layers of cell bodies and axonal and dendritic processes; i.e. nuclear and plexiform layers. Photoreceptors are located sclerad to second and third order neurons, including bipolar, horizontal, amacrine and ganglion cells situated closer to the vitreous [9-11]. Interestingly, the ganglion cells in the lamprey retina are mostly displaced to the inner nuclear layer (INL) near the inner plexiform layer (IPL) border with few ganglion cells situated in the middle of the IPL and adjoining the inner limiting membrane (Figure 1; $[12,13])$.

Beyond anatomical similarities, the expression of key phototransduction proteins including transducin, phosphodiesterase 6 and recoverin in the lamprey retina indicates the presence of a characteristic vertebrate visual system [14-17]. Immunoreactivity of retinal cell markers like calbindin (CalB), calretinin (CalR), choline acetyltransferase (ChAT) and glial fibrillary acidic protein (GFAP) have also been shown in the lamprey inner retina $[16,18-$ 21]. Characterisation of neurochemical pathways in the lamprey is limited. The major retinal amino acid neurotransmitters, glutamate, $\gamma$-aminobutyric acid (GABA) and glycine are present in the adult lamprey retina and show similar distribution patterns to other vertebrate retinae [22]. Other molecules such as dopamine and serotonin have also been detected although their role in the lamprey retina is unclear $[23,24]$. Overall, current data suggests 


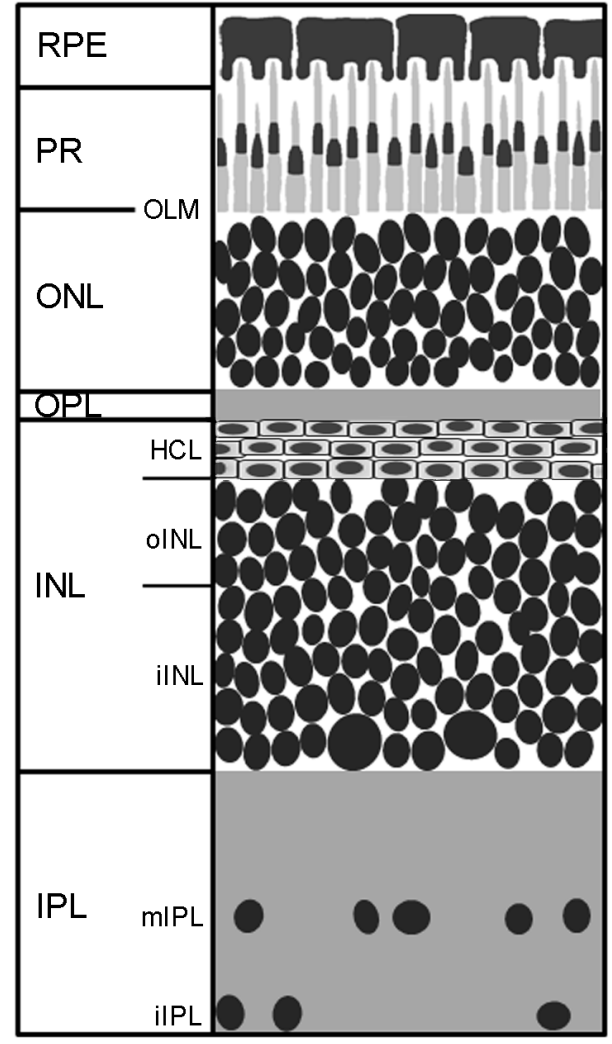

Downstream G. australis

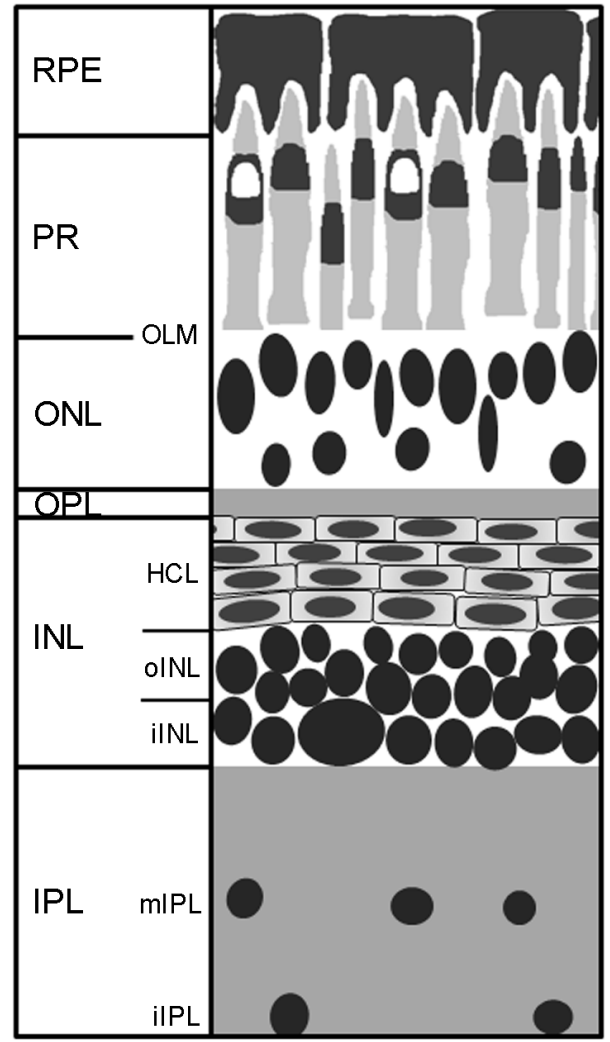

Upstream G. australis

Figure 1. Schematic of the retina of downstream and upstream migrants of G australis. The downstream G. australis retina is densely packed with over 10 layers of cells in the INL. The upstream G. australis retina is much larger; dominated by large photoreceptors and a reduced number of cell layers in the INL. The majority of the ganglion cells are displaced to the INL and a few orthotopic ganglion cells lie at the vitread border of the IPL and in the middle of the IPL. Figure is not drawn to scale. Abbreviations - RPE: retinal pigment epithelium, PR: photoreceptors, OLM: outer limiting membrane, ONL: outer nuclear layer, OPL: outer plexiform layer, INL: inner nuclear layer, HCL: horizontal cell layer, oINL: outer INL, iINL: inner INL, IPL: inner plexiform layer, mIPL: mid IPL, ilPL: inner IPL.

doi:10.1371/journal.pone.0058406.g001

that the lamprey can provide clues to the evolution of the visual and nervous systems of gnathostome vertebrates.

The majority of lamprey species are found in the northern hemisphere and belong to the family Petromyzontidae [25]. Extensive work has focused on northern hemisphere species, particularly Petromyzon marinus, Lampetra fluviatilis and Ichthyomyzon unicuspis. These animals have two structurally and spectrally distinct photoreceptor types, proposed as a rod-like and a cone-like photoreceptor although this classification is still subject to debate (reviewed in $[3,26,27])$. Four species of lamprey are native to the southern hemisphere and have been placed into two families, the Geotriidae and Mordaciidae [28,29]. Geotria australis is the only member of the Geotriidae and is found in New Zealand, Southern Australia, Chile and Argentina [28,29]. Unlike its northern hemisphere relatives, the retina of $G$. australis contains five distinct cone-like photoreceptors and five different opsin proteins [3,3032]. These opsins have been identified as direct orthologues of the long wavelength sensitive (LWS), short wavelength sensitive (SWS1 and SWS2) and medium wavelength sensitive (RHA/ $\mathrm{RH} 1$ and $\mathrm{RHB} / \mathrm{RH} 2$ ) opsins found in jawed vertebrates $[31,33,34]$.

Here, we seek to further understand the neurochemistry of the lamprey retina by investigating the amino acid distribution in the retina of $G$. australis. G. australis was selected as it features a complex (possibly pentachromatic) visual system, which may provide greater insight into the neurochemistry of colour vision than the dichromatic visual system of its northern hemisphere counterparts [35]. Furthermore, the retinal plasticity observed between the different migratory phases of $G$. australis (Figure 1) provides a unique opportunity to investigate changes in neurochemical pathways according to environmental pressures. Downstream migrants of $G$. australis (characterized as recently metamorphosed adults travelling from freshwater rivers to the ocean) possess a short and densely packed photoreceptor layer, likely to reflect its highly photopic habitat of shallow fresh water rivers [30,32,36]. However, upstream migrants (older fish returning from the sea into freshwater to breed) have retinas dominated by large photoreceptor cells [30,31,37]. The yellow myeloid pigment present in one of the photoreceptor types $(\mathrm{C} 2)$ of the downstream migrants is also replaced in the upstream migrating $G$. australis with a large unpigmented ellipsosome, resulting in a shift in the peak spectral sensitivity $\left(\lambda_{\max }\right)$ from $492 \mathrm{~nm}$ to $552 \mathrm{~nm}[30,32,38]$. These changes possibly reflect selective pressures produced by the changing light environment as adult lampreys in the ocean avoid avian predators at the surface when they move back up to their natal streams by adopting a scotopic lifestyle $[3,30]$. In this study, we will investigate key amino acid neurotransmitters in the retina of $G$. australis using immunocytochemical techniques and deter- 
mine if their distribution is associated with the anatomical differences found in the retina of downstream and upstream migrants. We will also investigate glutamate signalling by analysing cation channel permeability using the small organic cation, agmatine (AGB) and briefly assess the role of calcium, based on the distribution of calcium binding proteins.

\section{Materials and Methods}

\section{Ethics Statement}

This study was carried out in strict accordance with the recommendations in the Guide for the Care and Use of Laboratory Animals of the National Institutes of Health. Animals were killed with an overdose of methane tricaine sulfonate salt in concordance with ethical guidelines of the National Health and Medical Research Council of Australia, and all efforts were made to minimize suffering. All experimental protocols were approved by The University of Queensland Animal Ethics Committee.

\section{Animals}

Adult $G$. australis were collected as young, downstream migrants $(75-110 \mathrm{~mm}$ in length; $\mathrm{n}=9)$ or upstream migrants $(560-640 \mathrm{~mm}$ in length; $n=8$ ) from streams and rivers in south-western Australia using an electric fish shocker as described previously [3]. Animals were maintained in laboratory aquaria at $17^{\circ} \mathrm{C}$ under a $12 \mathrm{~h}$ light/dark cycle under Queensland Government Department of Primary Industries General Fisheries Permit, Stock Impoundment No: PRM01814G.

\section{Post-embedding Immunocytochemistry}

The procedures for post-embedding immunocytochemistry have been previously described [39-42]. Briefly, eyes were enucleated and isolated retinal pieces were immediately fixed in $2.5 \%(\mathrm{w} / \mathrm{v})$ glutaraldehyde, $1 \%(\mathrm{w} / \mathrm{v})$ paraformaldehyde in $0.1 \mathrm{M}$ phosphate buffer (PB, pH 7.4) for at least $30 \mathrm{~min}$ to preserve amino acid neurochemistry. Retinal pieces were washed in $\mathrm{PB}$ and dehydrated through a series of cold methanol washes to acetone followed by impregnating in resin. Resin blocks were serially sectioned at $0.25 \mu \mathrm{m}$ and collected on Teflon-coated slides. Before incubation with primary antibodies, the resin was etched with sodium ethoxide:ethanol (1:5) and the tissue washed with a graded methanol series to PB. Tissues were then incubated with $1 \%(\mathrm{w} / \mathrm{v})$ sodium borohydride for $30 \mathrm{~min}$ and air dried.

Primary antibodies for glutamate, glycine, glutamine, GABA, taurine and aspartate were diluted with $1 \%(\mathrm{v} / \mathrm{v})$ goat serum in phosphate buffered saline (GSPBS) and incubated with tissues overnight. Specifications and working dilutions for these antibodies are described in Table 1 . The primary antibodies were detected with goat anti-rabbit secondary antibodies (British BioCell, UK) coated with a $1 \mathrm{~nm}$ gold particle diluted in GSPBS (1:100) for 1$4 \mathrm{~h}$ at room temperature. The immunogold was visualized by silver intensification as described previously [39,40,42].

Images were acquired using a LEICA DC500 camera, version 4.1.0.0 attached to a LEICA microscope (Leica Microsystems Ltd, Heerbrugg, Germany). All images were captured using fixed parameters of exposure time, intensity, contrast, gamma, brightness and eight-bit channel.

Toluidine blue stained upstream and downstream specimens were used in the drawing of schematics of the retina (Figure 1). For putative glycinergic interplexiform cells, serial $250 \mathrm{~nm}$ sections were stained for glycine and viewed with the aid of a camera lucida to determine the morphology of major glycine interplexiform cell dendrites.
Cell identification was based on anatomical classification described in previous studies of the lamprey retina $[3,4,10,30]$. Briefly, cells were classified as photoreceptors, horizontal cells, bipolar cells, interplexiform cells or amacrine/ganglion cells based on retinal location and cell size. For bipolar cells, axon distribution was used to confirm identity. Amacrine and ganglion cells were grouped as a single class as the majority of the ganglion cells in the lamprey are displaced to the INL and cannot be differentiated from amacrine cells on anatomical features alone [12].

\section{AGB Incubation}

Isolated eye cup pieces were mounted on $0.8 \mu \mathrm{m}$ pore metrical membrane filters (Gelman Sciences, Ann Arbor, MI) and the sclera/retinal pigment epithelium removed by gently pulling it away from the retina. Retinal pieces were then incubated for 560 min at room temperature $\left(\sim 20^{\circ} \mathrm{C}\right)$ under normal room lighting (300-400 lux) in a modified Edwards medium (125 mM NaCl, $2.5 \mathrm{mM} \mathrm{KCl}, 26 \mathrm{mM} \mathrm{NaHCO}, 1.25 \mathrm{mM} \mathrm{NaH} \mathrm{PO}_{4}, 10 \mathrm{mM}$ dextrose, $2 \mathrm{mM} \mathrm{CaCl}_{2}, 1 \mathrm{mM} \mathrm{\textrm {MgCl } _ { 2 }}$, pH 7.4) bubbled with $95 \%$ $\mathrm{O}_{2 / 5} \% \mathrm{CO}_{2}$ [43]. For tissue incubated with AGB, $25 \mathrm{mM}$ AGB was added to the medium and an equimolar reduction in $\mathrm{NaCl}$ concentration was made. Retinal pieces were then fixed and processed for immunocytochemistry.

\section{Indirect Immunocytochemistry}

Retinal pieces were fixed in $4 \%(\mathrm{w} / \mathrm{v})$ paraformaldehyde, $0.01 \%$ $(\mathrm{w} / \mathrm{v})$ glutaraldehyde in $\mathrm{PB}$ for $30 \mathrm{~min}$ and then cryoprotected in $30 \%(\mathrm{w} / \mathrm{v})$ sucrose overnight. Frozen vertical sections were collected on positively charged slides (Lomb Scientific, Taren Point, NSW, Australia). Tissues were blocked with $6 \%$ (v/v) goat serum, $1 \%(\mathrm{v} / \mathrm{v})$ bovine serum albumin and $0.5 \%(\mathrm{v} / \mathrm{v})$ Triton X100 in $\mathrm{PB}$ for $1 \mathrm{~h}$ at room temperature followed by incubation with primary antibodies, diluted in $3 \%(\mathrm{v} / \mathrm{v})$ goat serum, $1 \%(\mathrm{v} / \mathrm{v})$ bovine serum albumin and $0.5 \%(\mathrm{v} / \mathrm{v})$ Triton $\mathrm{X}-100$ in $\mathrm{PB}$ overnight at $4^{\circ} \mathrm{C}$. Details and dilutions of the primary antibodies used for indirect immunocytochemistry are provided in Table 2.

Primary antibodies were detected with an anti-goat secondary antibody conjugated to AlexaFluor488 (Molecular Probes, Eugene, OR) diluted in 1:500 in $3 \%(\mathrm{v} / \mathrm{v})$ goat serum, $1 \%(\mathrm{v} / \mathrm{v})$ bovine serum albumin and $0.5 \%(\mathrm{v} / \mathrm{v})$ Triton X-100 in PB. The specificity of secondary antibodies was confirmed by omitting the primary antibody and using a secondary antibody from a different species. Fluorescence images were captured using a confocal laser scanning microscope (LEICA Microsystems TCS 4D). Image brightness and contrast was adjusted using Adobe Photoshop (version 6; Adobe Systems, Mountain View, CA, USA).

\section{Antibody Characterization}

For the amino acid antibodies, the specificity of the glutamate antibody was previously shown in dot immunoassays where a positive signal for the glutamate antibody was obtained against an artificial glutamate antigen coupled to bovine serum albumin (BSA) via glutaraldehyde cross-linking [40]. Comparable results were observed for GABA, glycine, aspartate, taurine and glutamine antibodies against glutaraldehyde cross-linked GABA, glycine, aspartate, taurine and glutamine antigens respectively $[40,41,44]$. No cross-reactivity was observed with amino acids other than that of the antibody target (manufacturer's data sheet, [40]). The specificity of the AGB antibody has been confirmed with dot blot immunoassays which report no cross reactivity with other amino acids [45]. No endogenous AGB activity has been detected in the vertebrate retina [45-47].

The specificity of the calbindin antibody was established in immunoblots yielding a single $28 \mathrm{kDa}$ band corresponding to the 
Table 1. Amino acid primary antibodies used in this study.

\begin{tabular}{|c|c|c|c|}
\hline Antigen & Immunogen & Manufacturer, Cat No & Dilution \\
\hline Aspartate & $\begin{array}{l}\text { Aspartate conjugated to bovine serum albumin } \\
\text { with glutaraldehyde }\end{array}$ & $\begin{array}{l}\text { Signature Immunologics (D100); Gift from } \\
\text { Dr R. E. Marc }\end{array}$ & $1: 400$ \\
\hline Gamma-aminobutyric acid (GABA) & $\begin{array}{l}\text { GABA conjugated to bovine serum albumin } \\
\text { with glutaraldehyde }\end{array}$ & $\begin{array}{l}\text { Chemicon (AB5016); Signature Immunologics } \\
\text { (YY100); Gift from Dr R. E. Marc }\end{array}$ & $1: 4500$ \\
\hline Glutamate & $\begin{array}{l}\text { Glutamate conjugated to bovine serum albumin } \\
\text { with glutaraldehyde }\end{array}$ & $\begin{array}{l}\text { Chemicon (AB5018); Signature Immunologics } \\
\text { (E100); Gift from Dr R. E. Marc }\end{array}$ & $1: 4500$ \\
\hline Glutamine & $\begin{array}{l}\text { Glutamine conjugated to bovine serum albumin } \\
\text { with glutaraldehyde }\end{array}$ & $\begin{array}{l}\text { Chemicon (AB5012); Signature Immunologics } \\
\text { (Q100); Gift from Dr R. E. Marc }\end{array}$ & 1:4000 \\
\hline Glycine & $\begin{array}{l}\text { Glycine conjugated to bovine serum albumin } \\
\text { with glutaraldehyde }\end{array}$ & $\begin{array}{l}\text { Chemicon (AB5020); Signature Immunologics } \\
\text { (G100); Gift from Dr R. E. Marc }\end{array}$ & $1: 4000$ \\
\hline Taurine & $\begin{array}{l}\text { Taurine conjugated to bovine serum albumin } \\
\text { with glutaraldehyde }\end{array}$ & $\begin{array}{l}\text { Chemicon (AB5022); Signature Immunologics } \\
\text { (TT100); Gift from Dr R. E. Marc }\end{array}$ & 1:1000 \\
\hline
\end{tabular}

The antibodies used for this study were kindly donated by Dr R. E. Marc but are now also commercially available through Chemicon and Signature Immunologics. All antibodies are rabbit polyclonal.

doi:10.1371/journal.pone.0058406.t001

expected calbindin protein (manufacturer's data sheet). Specificity of the calretinin antibody has been confirmed by Western blots of mouse brain lysate which show the antibody reacting with a single $31 \mathrm{kDa}$ band corresponding to the expected size for the calretinin protein (manufacturer's data sheet). The specificity of the glutamine synthetase (GS) antibody was confirmed with a Western blot using rat cerebellum lysate where it reacted with a $45 \mathrm{kDa}$ band which corresponds to the expected size of the GS protein, amino acids 1-373 (BD Biosciences technical data sheet). The specificity of protein kinase $\mathrm{C}-\alpha(\mathrm{PKC} \alpha)$ antibody was confirmed in a Western Blot of rat glioma extract and NIH 3T3 mouse fibroblast lysate where the antibody reacted with a single $80 \mathrm{kDa}$ band corresponding the expected size for PKC $\alpha$. Finally, the specificity of the recoverin antibody was confirmed as the presence of single $26 \mathrm{kDa}$ band in Western blots of human adult retina tissue homogenate [48].

\section{Results}

\section{Retinal Anatomy of Downstream and Upstream Migrants}

Figure 1 is a schematic representation of the lamprey retina based upon Nissl stained sections [49]. In contrast to many vertebrates, the majority of the ganglion cells in the lamprey are displaced to the INL and the nerve fibre layer is found between the INL and inner plexiform layer (IPL). A few orthotopic ganglion cells lie at the vitread border of the IPL and in the middle of the
IPL. The downstream $G$. australis retina features 5 different conelike photoreceptors and densely packed INL with over 10 layers of cells including at least three, possibly four layers of horizontal cells (S.P. Collin, unpublished data). The upstream G. australis retina is much thicker; dominated by large photoreceptors, some with an altered morphology (e.g. the C2 photoreceptor replaces a photostable pigment with an unpigmented ellipsosome). The number of cell layers in the INL appears reduced but four layers of horizontal cells are visible. Similar to other vertebrates, the lamprey retina has a pigmented epithelium.

\section{Glutamate Immunoreactivity of $G$. australis retina}

Glutamate immunoreactivity was observed to some degree in all retinal cells of the downstream and upstream migrant of $G$. australis (Figure 2). In the downstream migrant, many cell somata were labelled in the outer nuclear layer (ONL) and there was a clear division between the weakly stained cells in the outer ONL and strongly stained cells in the inner part of the ONL (Figure 2A, white arrowheads). For the upstream migrant, at least two different photoreceptor types were labelled in the ONL; a large soma type in the middle of the ONL and a small cell soma located close to the ONL-OPL border (Figure 2B, white arrowheads). The inner nuclear layer (INL) also showed heterogeneous labelling with high levels of glutamate immunoreactivity in the outer INL. Glutamate was uniformly distributed across the horizontal cell layer for both

Table 2. Primary antibodies used in the immunofluorescence protocol.

\begin{tabular}{|c|c|c|c|c|}
\hline Antigen & Immunogen & Manufacturer, Cat No & Host & Dilution \\
\hline Agmatine (AGB) & $\begin{array}{l}\text { Agmatine conjugated to bovine serum } \\
\text { albumin }\end{array}$ & Chemicon; AB1568* & $\mathrm{Rb}$; polyclonal & $1: 100$ \\
\hline Calbindin (CalB) & bovine kidney calbindin-D & Sigma-Aldrich; C9848 & Ms; monoclonal & $1: 1000$ \\
\hline Calretinin (CaIR) & Recombinant rat calretinin & Millipore; MAB1568 & Ms; monoclonal & $1: 1000$ \\
\hline Glutamine synthetase (GS) & $\begin{array}{l}\text { Recombinant sheep GS, amino acids } \\
1-373\end{array}$ & $\begin{array}{l}\text { BD Transduction Laboratories; } \\
610517\end{array}$ & Ms; monoclonal & $1: 3000$ \\
\hline Protein kinase $\mathrm{C}-\alpha(\mathrm{PKC} \alpha)$ & Purified bovine brain PKC & Sigma-Aldrich; P5704 & Ms; monoclonal & $1: 400$ \\
\hline Recoverin & Recombinant human recoverin & Chemicon; AB5585 & $\mathrm{Rb}$; polyclonal & 1:1000 \\
\hline
\end{tabular}

*This antibody was kindly donated by $\operatorname{Dr}$ R. E. Marc but is also commercially available through Chemicon.

doi:10.1371/journal.pone.0058406.t002 

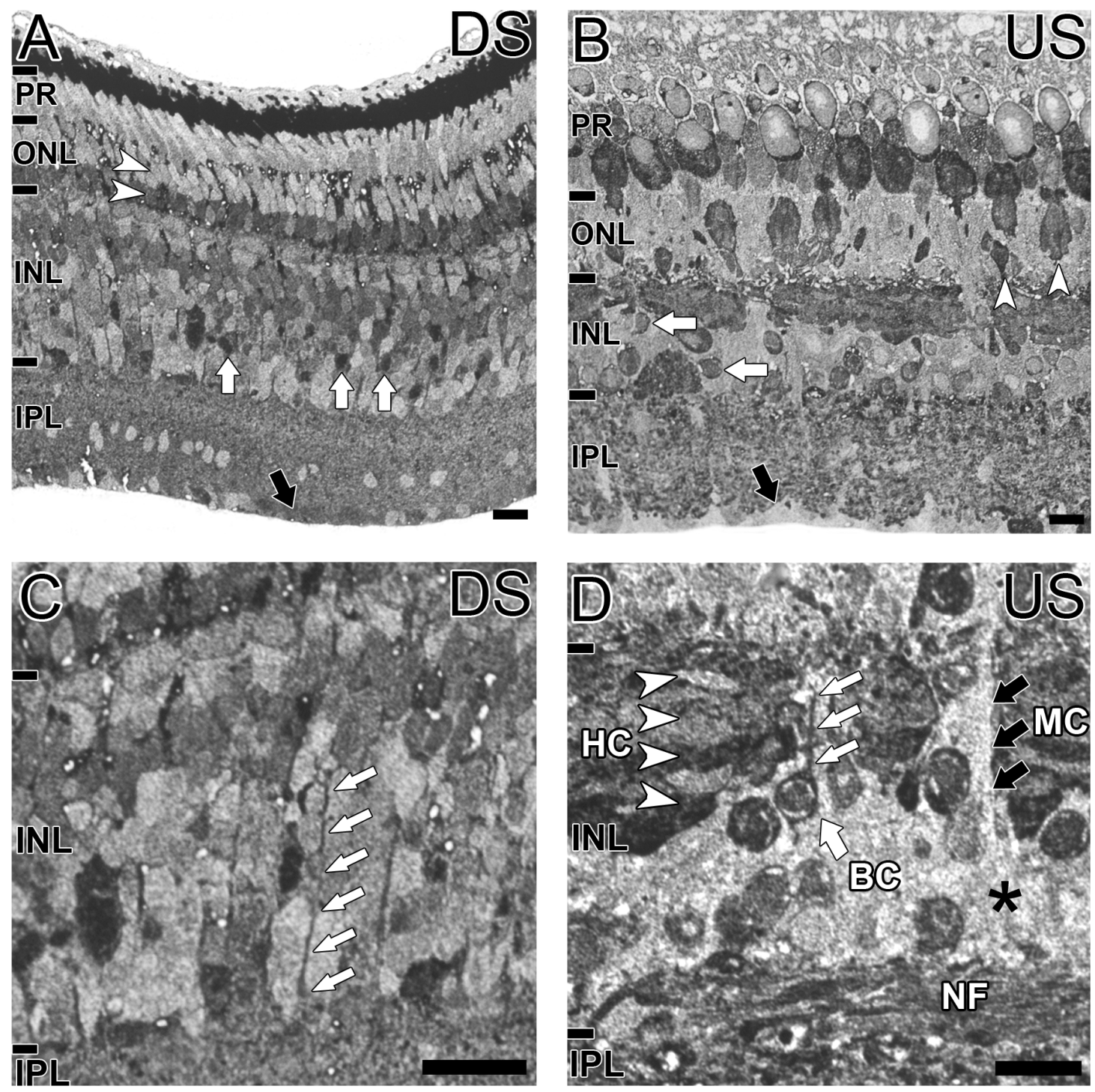

Figure 2. Localization of glutamate in the G. australis retina. Glutamate immunoreactivity in the $\mathbf{A}, \mathbf{C}$ : downstream migrant (DS) and $\mathbf{B}, \mathbf{D}$ : upstream migrant (US) of G. australis. A: Glutamate immunoreactivity in the downstream migrant was observed in the ONL at different intensities (white arrowheads). Strong immunoreactivity was also seen in some cells in the INL (white arrows) and Müller cell endfeet (black arrow). B: In the upstream migrant, numerous large and small photoreceptor cells were immunoreactive (white arrowheads), as well as other INL cells (white arrows). Müller cell endfeet displayed low glutamate immunoreactivity (black arrow). Magnified images confirm that C: Müller cells in the downstream migrant were immunoreactive for glutamate (white arrows) and D: horizontal cells (HC; white arrowheads), putative bipolar cells (BC; white arrows) and the nerve fiber layer (NF) are glutamate immunoreactive in the upstream migrant. Müller cell (MC) somata (asterisk) and processes (black arrows) were immunonegative. Retinal layers are denoted by the lines and annotations on the left of each image and include the photoreceptors (PR), outer nuclear layer (ONL), inner nuclear layer (INL) and inner plexiform layer (IPL). Note that due to the small thickness of the OPL, it was not labelled for clarity. Scale bar for all images is $20 \mu \mathrm{m}$.

doi:10.1371/journal.pone.0058406.g002

animals except for disruptions by the Müller cell processes (Figure 2D, black arrows).

Many cells in the inner INL of the downstream migrant of $G$. australis showed a moderate level of staining but some were intensely stained (Figure 2A, white arrows). These cells could not all be confirmed as amacrine cells as many lamprey ganglion cells are displaced to the inner INL [12]. Glutamate immunoreactive cells processes traversing the INL appeared to display Müller cell morphological characteristics (Figure 2C, white arrows). The most proximal part of the retinal, where Müller cell endfeet terminate, was glutamate immunoreactive (Figure 2A, black arrow). In the upstream migrant, several cell types in the INL were strongly glutamate immunoreactive (Figure 2B, white arrows). Müller cell endfeet in the most proximal part of the retina display low glutamate (Figure 2B, black arrow) and Müller cell somata (Figure 2D, asterisk) display low levels of glutamate. Figure 2D highlights a labelled cell with is axon extending towards the outer retina suggesting bipolar cells are glutamate immunoreactive. Four layers of glutamate immunoreactive horizontal cells were also clearly evident (Figure 2D, white arrowheads). We performed PKC $\alpha$ labelling to further confirm bipolar cell identity but did not yield any distinct soma labelling in the retinae of downstream or upstream migrants (Figure S1). 


\section{GABA Immunoreactivity of $G$. australis Retina}

GABA immunoreactivity was almost identical between downstream and upstream migrating animals, restricted mostly to the inner retina (Figure 3). A band of weakly GABA immunoreactivity cells were evident in the outer INL of the downstream migrant (Figure 3A, white arrow) and more sparingly in the upstream migrant (Figure 3B, white arrows). Closer inspection suggests these cells as bipolar cells with evidence of processes extending into the outer plexiform layer (OPL; Figure 3C-D). At least two distinct layers of highly immunoreactive horizontal cells were evident in the downstream migrant (Figure 3C, white arrowheads) and three layers of horizontal cells were strongly GABA immunoreactive in the upstream migrant (Figure 3E, white arrowheads). Most cells of the inner INL were strongly labelled for GABA in both animals. Intense GABA labelling was also present in the IPL of both animals and some cells along the vitreous IPL border (Figure 3A$\mathrm{B}$, black arrows). In both upstream and downstream migrant retinas, the most proximal retina showed low GABA immunoreactivity indicating Müller cell endfeet do not have constitutively high levels of this amino acid.

\section{Glycine Immunoreactivity of G. australis}

Glycine was mostly restricted to the inner retina of $G$. australis (Figure 4). In the downstream animal, glycine immunoreactive cells were present in the inner INL and displayed varied levels of labelling (Figure 4A). Some glycine immunoreactivity was also evident in the outer retina. Glycine immunoreactive cells of the upstream migrant however were more concentrated along the INL - IPL border (Figure 4B, black arrow). Additionally, intense glycine reactive processes were observed throughout the IPL of the upstream migrant of $G$. australis but not the downstream migrant. Glycinergic cells in the mid and inner IPL were observed in the both animals (Figure 4A-B, white arrows).

A few isolated cells in the outer INL were also strongly glycine immunoreactive in both animals (Figure 4A-B, white arrowheads). These cells are thought to be putative glycinergic interplexiform cells with evidence of the major processes extending towards the IPL and OPL (Figure 4C-F). The punctate glycine immunoreactivity seen in the OPL is likely to reflect their cell processes.

\section{Glutamine Immunoreactivity of $G$. australis Retina}

Glutamine immunoreactivity differed considerably between the migratory phases of $G$. australis. Weak glutamine immunoreactivity was observed across the retina of the downstream migrant except for few intensely stained somata observed in the mid INL (Figure 5A, white arrowheads). These cells are likely to be Müller cells as magnified images show columns of glutamine immunoreactivity corresponding to typical pattern of Müller cell processes traversing the ONL (Figure 5A, C, white arrows). Glutamine synthetase (GS) immunoreactivity also closely matched glutamine immunoreactivity, present as punctuate labelling along the outer limiting membrane (OLM; Figure 5E, large white arrow) and immunoreactive processes extended across the entire retina (Figure 5E, small white arrows).

Glutamine immunoreactivity was more extensive in the upstream migrating $G$. australis, found throughout the outer and inner retina. Immunoreactivity was mostly concentrated to the surrounding cell matrix with many cell somata remaining immunonegative, particular horizontal cells (Figure 5B). Thick columns of glutamine immunoreactivity could be seen traversing the horizontal cell layer into the ONL (Figure 5D, white arrows). Somata at the base of these columns were likely Müller cells. Increased levels of GS labelling was also observed in the upstream migrant of $G$. australis (Figure $5 \mathrm{~F}$ ). The similarity of glutamine synthetase and glutamine immunoreactivity suggests the same cell type is being labelled.

\section{Aspartate Immunoreactivity of $G$. australis Retina}

In the downstream animal, aspartate was limited to a few cells in the mid and inner INL, similar to the immunoreactivity profile of glutamine (Figure 6A, white arrowheads). High aspartate immunoreactivity at the OLM also suggests the labelling of Müller cell microvilli (Figure 6C, white arrowhead). On the other hand, many cell types contained aspartate in the upstream migrating $G$. australis. In the ONL, a cell population near the photoreceptor layer and another near the ONL-OPL border were immunoreactive (Figure 6B, white arrowheads). Within the INL, some small cells in the outer INL (possibly bipolar cells) and a few cells at the INL-IPL border were labelled (Figure 6B, white arrows). Aspartate was also present in a number of horizontal cells and nerve fibers (Figure 6D, white arrowheads). Asparate labelled horizontal cells were co-localized with glutamate and GABA immunoreactivity (M. Kalloniatis, unpublished data).

\section{Taurine Immunoreactivity of G. australis Retina}

High levels of taurine were present throughout the downstream and upstream migrating $G$. australis retina particularly in the photoreceptors (Figure 7A-B). In the upstream migrant of $G$. australis, several photoreceptors types with varying sized somata were clearly labelled (Figure 7B, white arrowheads). Highly taurine immunoreactive cells were also obvious in the outer INL of both animals (Figure 7A-B, white arrows). In the upstream migrant of $G$. australis, these cells appeared to be bipolar cells with processes extending towards the outer retina, similar to glutamate labelled processes (Figure 7D, white arrows). We were unable to find distinct taurine labelled cell processes in the downstream migrant although their anatomical location suggests they were also bipolar cells. All horizontal cells of the downstream migrant had low taurine immunoreactivity whilst one horizontal layer in the upstream migrant was weakly taurine immunoreactive (Figure 7D, white arrowhead). Cells of the inner INL and IPL of both migrants were mostly immunonegative (Figure 7A, black arrows).

Interestingly, taurine immunoreactivity of Müller cells differed in the upstream and downstream migrant. Taurine immunoreactive cell processes could be seen throughout the retina of the downstream migrant and highly immunoreactive Müller cell endfeet were obvious at the vitreal IPL border (Figure 7C, E, white arrows). In contrast, we saw no obvious taurine labelling of Müller cell processes in the upstream migrant of $G$. australis and very little immunoreactivity was evident along the IPL-vitreous border (Figure 7F, white arrows). The large Müller cell and taurine immunoreactive somata (Figure 7B), display similar morphology to the glutamine synthetase and glutamine immunoreactivity.

\section{Cation Channel Permeability of Retinal Neurons in G. australis}

AGB is a small organic cation and can be used to map excitatory pathways regulated by glutamate activity in the retina [45,50-52]. We assessed basal cation channel permeability in upstream and downstream migrating animals using AGB. After a 5 min incubation with AGB, several photoreceptors and horizontal cells were strongly AGB immunoreactive in both upstream and downstream migrants of $G$. australis (Figure 8A-B). Weakly labelled cell bodies in the inner retina were also apparent. Longer incubation times (20-60 min) resulted in a successive increase in the number of AGB labelled cell somata in the INL (Figure 8C-F). In the downstream migrating $G$. australis, AGB immunoreactive 

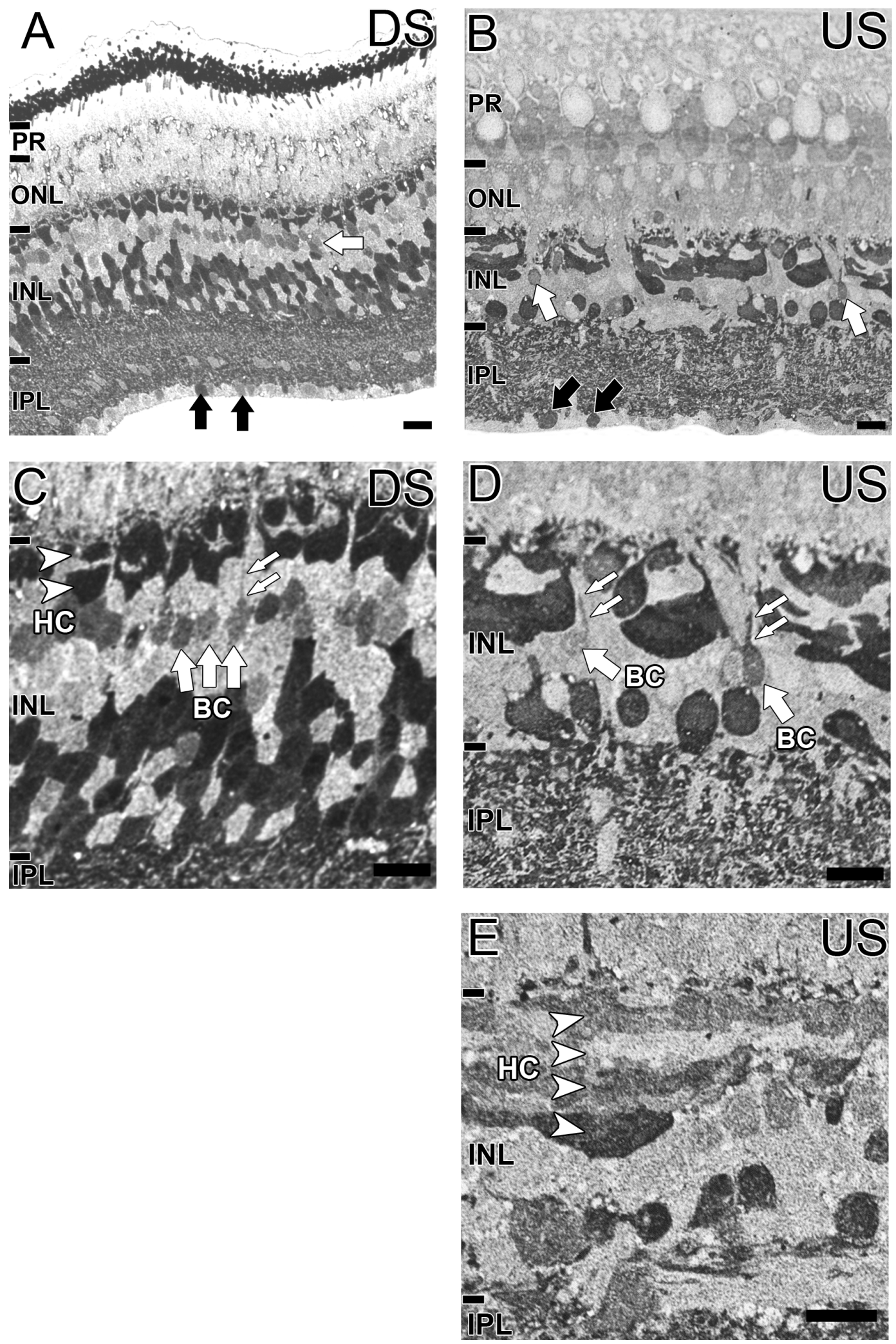

Figure 3. Localization of GABA in the G. australis retina. GABA immunoreactivity in the $\mathbf{A}$, C: downstream migrant and $\mathbf{B}$, D, E: upstream migrant of G. australis. A-B: GABA immunoreactivity of the whole retina. White arrows indicate weakly GABA positive bipolar cells and black arrows indicate GABA reactive cells in the IPL. C-E: Magnified images of the INL. White arrowheads indicate GABA immunoreactive horizontal cells (HC) and white arrows in highlight bipolar cell (BC) processes extending towards the outer plexiform layer. Abbreviations are as in Figure 2 . Scale bar is $20 \mu \mathrm{m}$ for all images.

doi:10.1371/journal.pone.0058406.g003 

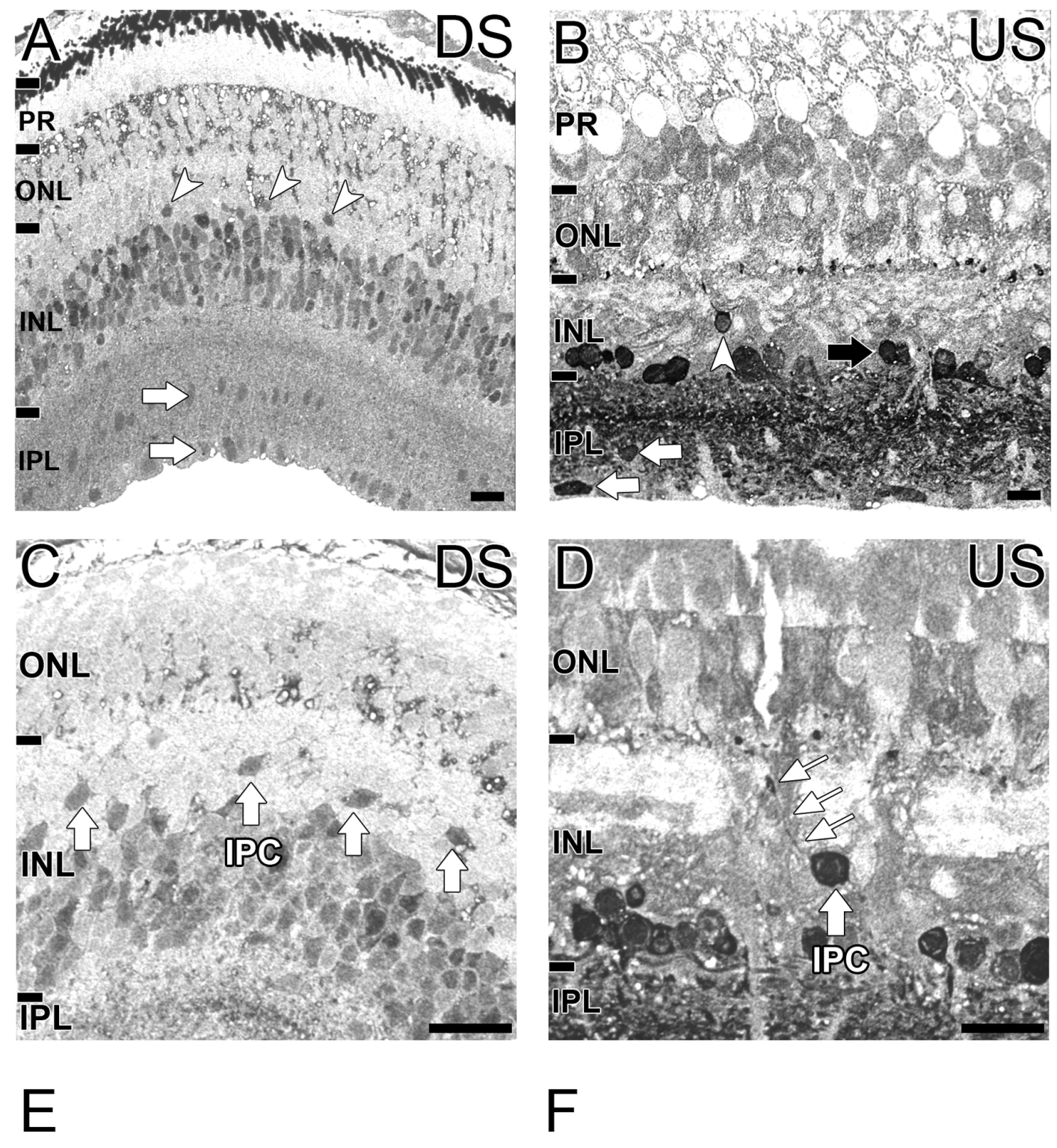

\section{$\mathrm{F}$}

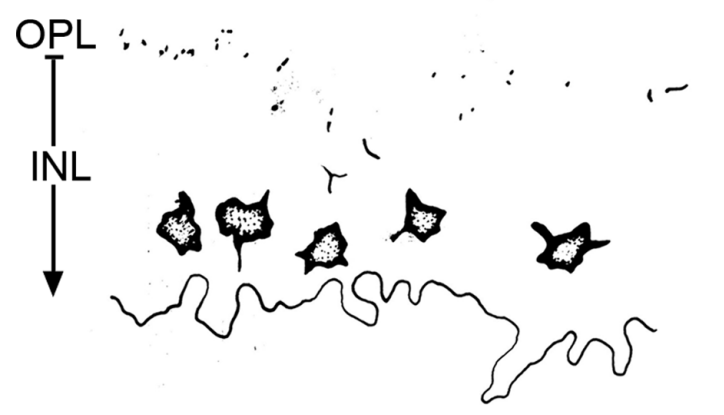

inner INL

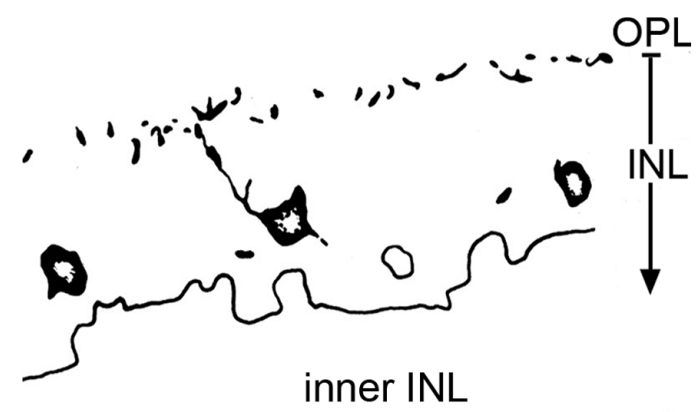

$$
1 \widetilde{0 \mu \mathrm{m}}
$$

$1 \longdiv { 0 \mu \mathrm { m } }$

Figure 4. Localization of glycine in the G. australis retina. Glycine immunoreactivity of A, C, E: the downstream migrant and B, D, F: upstream migrant of G. australis. A-B: Glycine immunoreactivity of total retina where white arrows indicate labelled cells in the mid and inner IPL and white arrowheads indicate strongly labelled putative interplexiform cells (IPC). C-D: Magnified images of putative glycine immunoreactive IPCs (white arrows). E-F: The morphology of putative glycinergic interplexiform cells and their dendrites drawn with the aid of a camera lucida. Abbreviations are as in Figure 2. Scale bar is $20 \mu \mathrm{m}$ in microscope images and $10 \mu \mathrm{m}$ in drawings. doi:10.1371/journal.pone.0058406.g004 

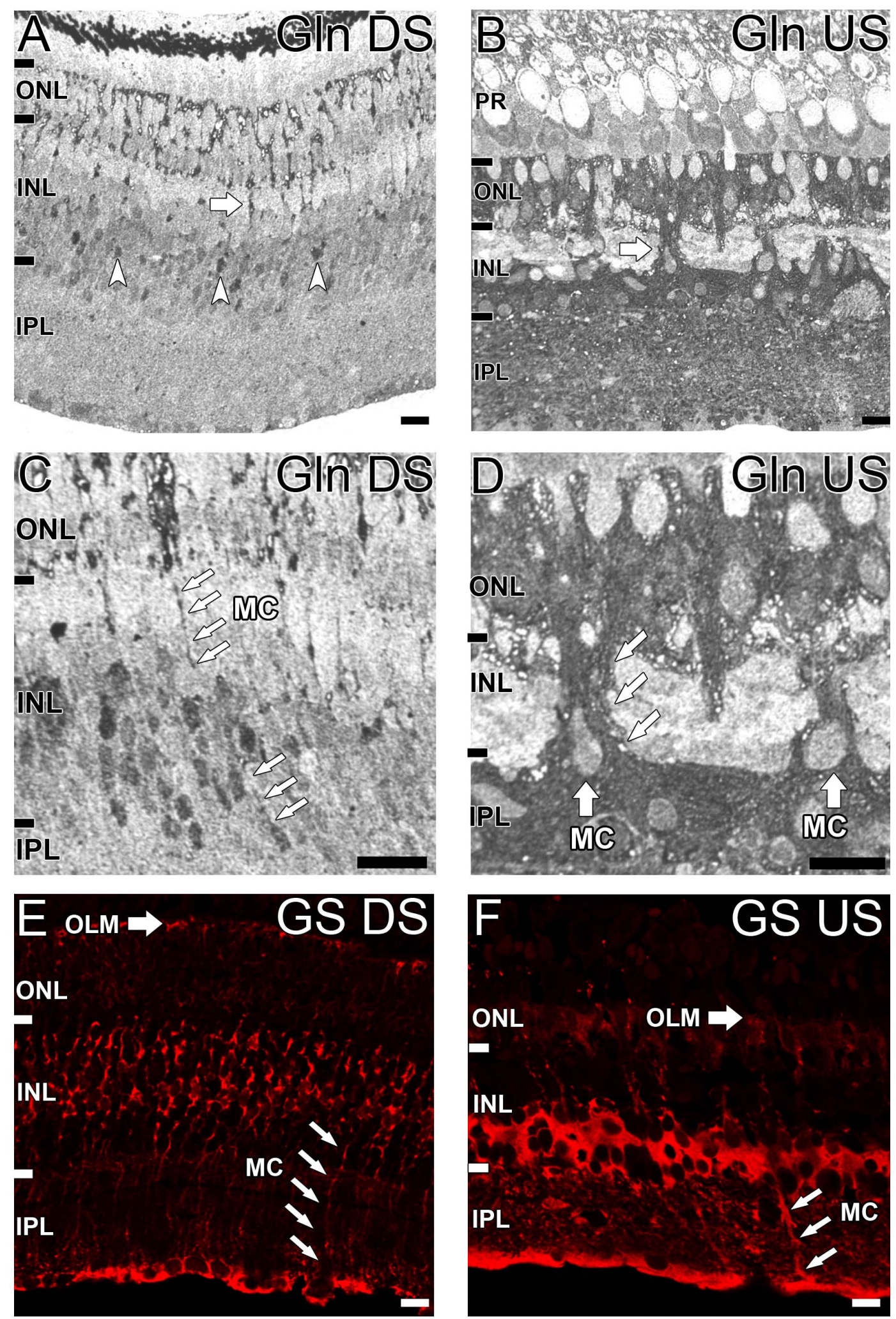

Figure 5. Localization of glutamine in the G. australis retina. Glutamine (Gln) immunoreactivity in the $\mathbf{A}, \mathbf{C}$ : downstream migrating (DS) and B, D: upstream (US) migrating G. australis. A-B: Glutamine immunoreactivity across the whole retina. White arrowheads indicate the few immunoreactive cell somata in the INL and white arrows indicate the columns of glutamine immunoreactivity extending towards the ONL. C-D: Magnified images of the INL demonstrating Müller cell processes traversing the retina (white arrows). Glutamine synthetase (GS) immunoreactivity was also determined in the E: downstream and F: upstream migrating G. australis. Müller cell (MC) processes are indicated with small white arrows and the immunoreactive outer limiting membrane (OLM) but a large white arrow. Abbreviations are as in Figure 2 . Scale bar is $20 \mu \mathrm{m}$ for all images. doi:10.1371/journal.pone.0058406.g005 

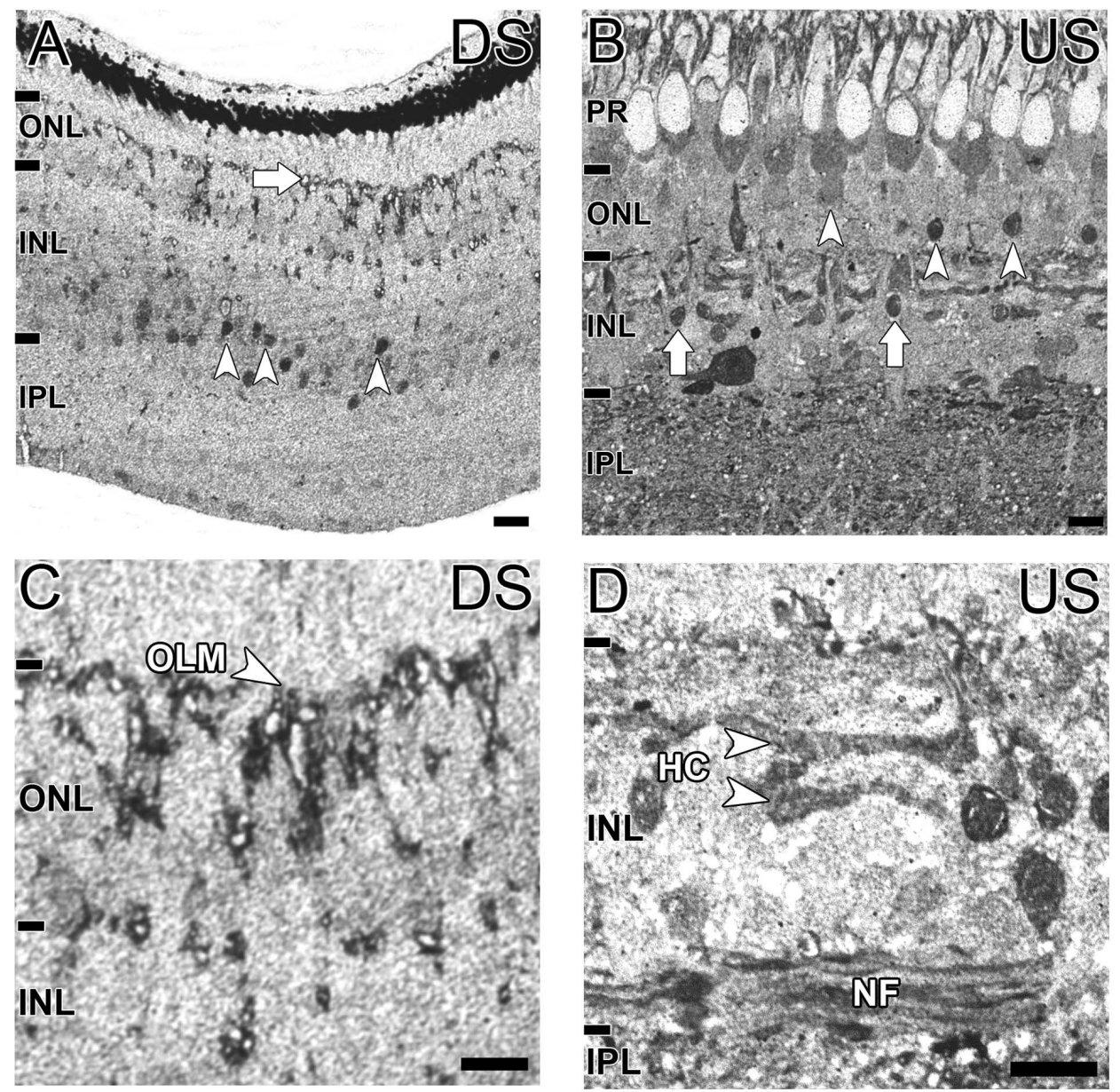

Figure 6. Localization of aspartate in the G. australis retina. Aspartate immunoreactivity in A, C: the downstream migrant and B, D: the upstream migrant of G. australis. A: Aspartate immunoreactivity for the downstream animals was confined to the mid INL (white arrowheads) and punctate staining along the outer limiting membrane (white arrow). B: Aspartate immunoreactivity in the upstream animal was observed in different photoreceptors (white arrowheads) and some small cells in the INL (white arrows). C: Magnified image of the downstream migrant retina showing aspartate immunoreactivity across the outer limiting membrane (OLM). D: Magnified image of the INL in the upstream migrating G. australis showing immunoreactive horizontal cells $(\mathrm{HC})$ and nerve fibers (NF) are indicated. Abbreviations are as in Figure 2. Scale bar is $20 \mu \mathrm{m}$ in all figures. doi:10.1371/journal.pone.0058406.g006

neurons were distributed throughout the inner half of the INL (Figure 8D, white arrows). By $60 \mathrm{~min}$, the strongest AGB immunoreactivity was localized to cells along the INL-IPL border and inner IPL (Figure 8F, white arrows). Distinct AGB immunoreactivity in the INL was not as obvious in the retina of the upstream migrating $G$. australis although many AGB labelled cells along the INL-IPL border could be seen after 60 min (Figure 8E, white arrows). Interestingly, no AGB was observed for cells in the mid IPL in both migrant animals. Many photoreceptors and all horizontal cells were strongly immunoreactive by the end of the AGB time course. Very little endogenous AGB was present in the G. australis retina (Figure $8 \mathrm{G}$ ).

\section{Distribution of Calcium Binding Proteins}

Calcium ions play a key role alongside amino acid neurotransmitters in signal transduction in the retina. Hence, we investigated the distribution of the calcium binding proteins, calbindin (CalB), calretinin (CalR) and the calcium sensitive protein, recoverin, to analyse calcium associated protein distribution in the retina of $G$. australis. Recoverin immunoreactivity was identical between the downstream and upstream migrants of $G$. australis, which was localized completely to photoreceptors (Figure 9A-B).
CalB immunoreactivity in the retina of the downstream migrating $G$. australis was found in the outer segment/inner segment of photoreceptors, horizontal cells and in the inner INL (Figure 9C). Staining, however, was fairly diffuse and individual cell bodies were difficult to distinguish. A triangular shaped cell body labelled in the ONL suggests that some photoreceptors may be CalB positive (Figure 9C, white arrowhead). Punctate staining present in the mid IPL suggested cells of the INL express CalB. A labelled cell soma in the inner IPL was also apparent (Figure 9C, white arrow). Immunoreactivity of the upstream migrant retina was similar to its downstream counterpart. All horizontal cells were CalB immunoreactive and some cell bodies in the inner INL were labelled. A number of CalB immunoreactive photoreceptors were evident in the ONL (Figure 9D, white arrowheads). Some isolated cells in the mid and inner IPL were also CalB immunoreactive (Figure 9D, white arrows).

CalR immunoreactivity was more conspicuous than CalB, distinctly labelling several cell somata in the inner retina (Figure 9E-F). For the downstream migrant, weak CalR staining was observed throughout the horizontal cell layer and several bipolar cells in the outer INL. Many cells in the inner INL were also labelled. Positive staining was seen for cells in the inner IPL 

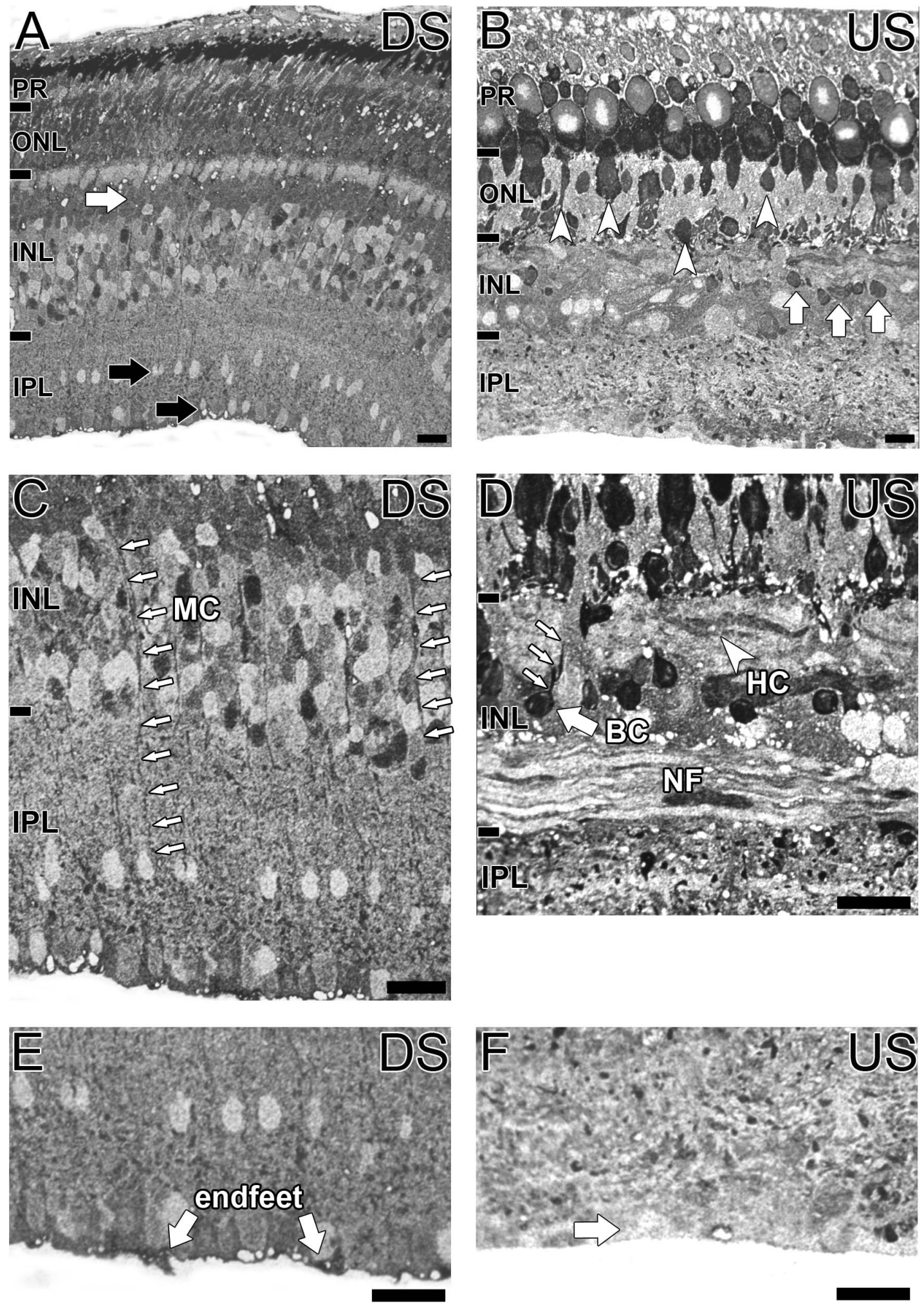

Figure 7. Localization of taurine in the $\mathbf{G}$. australis retina. Taurine immunoreactivity in $\mathbf{A}, \mathbf{C}$, E: the downstream migrant and $\mathbf{B}$, D, F: the upstream migrant of G. australis. A-B: Taurine immunoreactivity across the whole retina length. White arrows indicate putative taurine labelled bipolar cells, black arrows indicate weakly labelled IPL cells and white arrowheads indicate various photoreceptor types immunoreactive for taurine. C: Magnified image of the INL with white arrows indicating immunoreactive Müller cell processes. D: Magnified image of the INL in the upstream migrant of G. australis. Taurine immunoreactivity was present in a putative bipolar cell (BC; white arrows) and a weakly labelled horizontal cell (HC). Immunoreactivity was absent in nerve fibers (NF). E-F: Taurine immunoreactivity of vitreous-IPL border where Müller cell endfeet are located. Abbreviations are as in Figure 2. Scale bar is $20 \mu \mathrm{m}$.

doi:10.1371/journal.pone.0058406.g007 

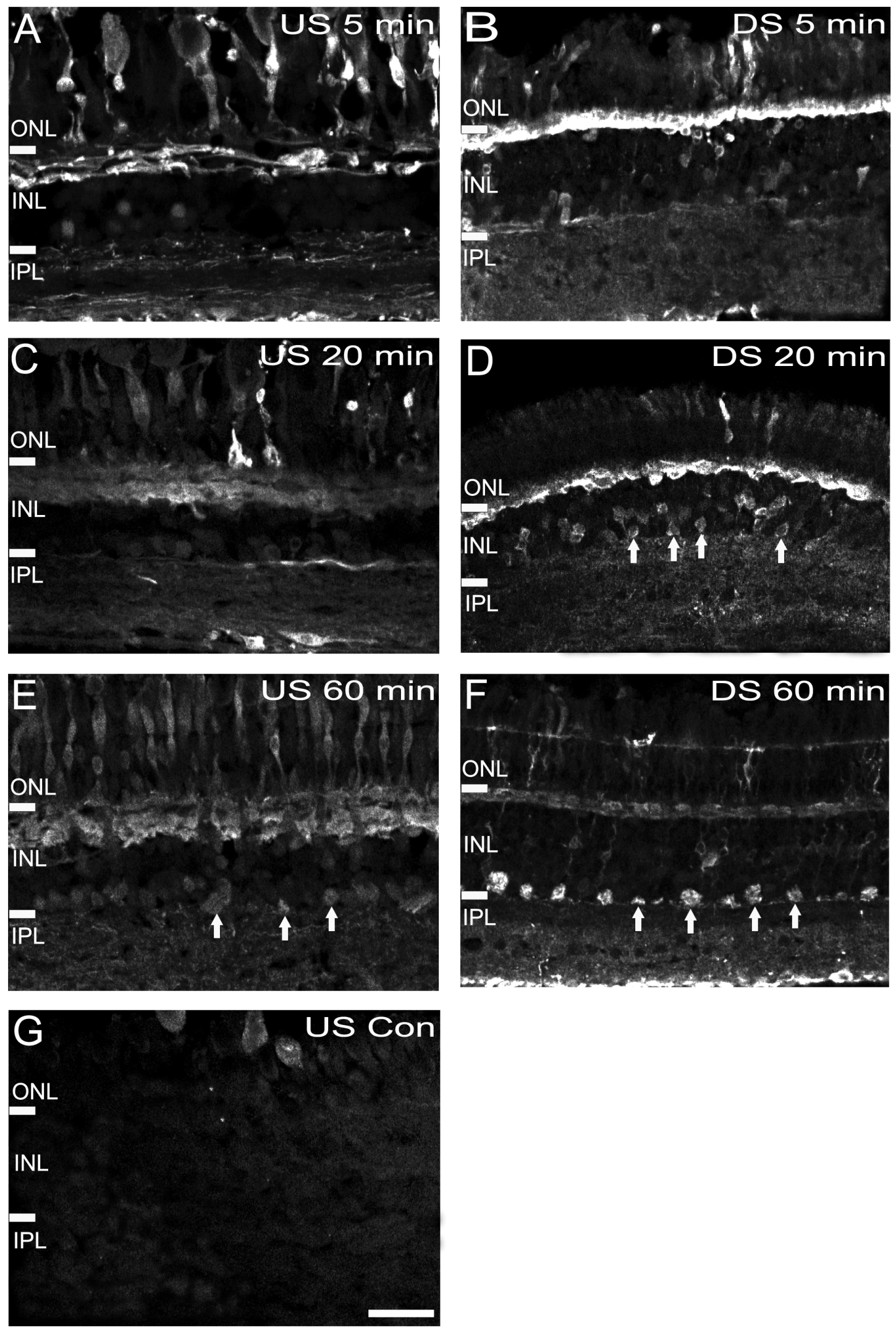

Figure 8. Cation channel permeability based on AGB immunoreactivity. Retinas of downstream (DS) and upstream (US) migrating G. australis were incubated for A-B: $5 \mathrm{~min}$, C-D: $20 \mathrm{~min}, \mathbf{E - F}: 60 \mathrm{~min}$ and G: 0 min with AGB. AGB labelled cells in the INL are indicated with white arrows. Abbreviations are as in Figure 2. Scale bar is $20 \mu \mathrm{m}$. doi:10.1371/journal.pone.0058406.g008 

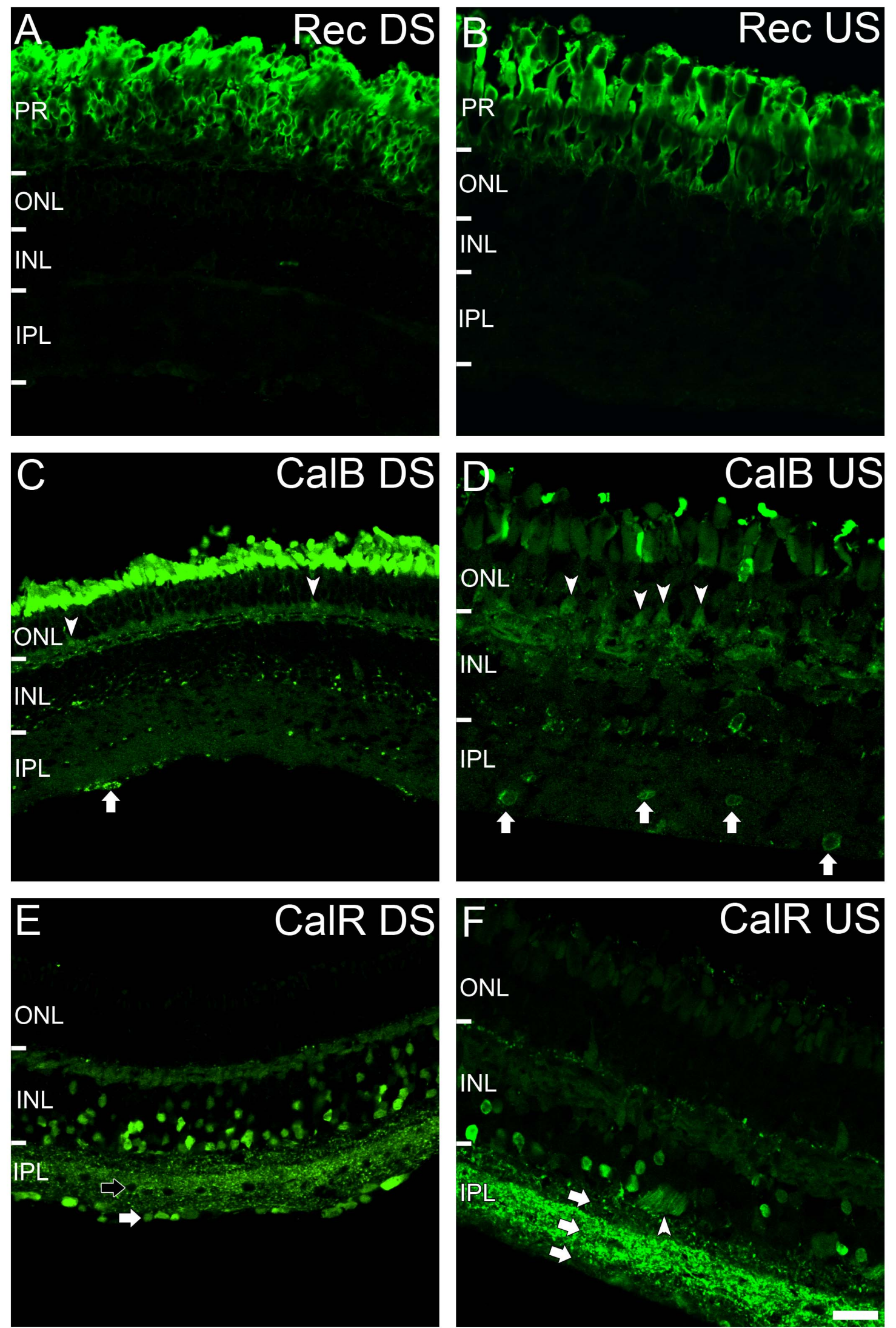

Figure 9. Distribution of calcium binding proteins in the retina of $G$. australis. Recoverin (Rec) immunoreactivity in the A: downstream (DS) migrating and B: upstream (US) migrating G. australis. Calbindin (CalB) immunoreactivity in the C: downstream migrating and D: upstream migrating G. australis. Labelled photoreceptors and IPL cells are denoted by white arrowheads and arrows respectively. Calretinin (CaIR) immunoreactivity in the 
E: downstream migrating and F: upstream migrating G. australis. In the downstream migrating animal (E), CaIR immunoreactive cells in the inner IPL were found near the inner limiting membrane (white arrow) but not in the mid IPL (black arrow). In the upstream migrating animal (F), three different bands of CalR intensity was present in the IPL (white arrows). The white arrowhead indicates labelled nerve fibers. Abbreviations are as in Figure 2. Scale bar is $50 \mu \mathrm{m}$.

doi:10.1371/journal.pone.0058406.g009

(Figure 9E, white arrow) but absent in cells in the mid IPL (Figure 9E, black arrow). This pattern of immunoreactivity was matched in the upstream migrating $G$. australis with weak CalR immunoreactivity present in outer INL and strong labelling of the inner INL (Figure 9F). Labelling of nerve fibers (Figure 9F, white arrowhead) suggests that ganglion cells expressed CalR. Punctate staining was evident throughout the IPL, distributed into three distinct layers; an intensely stained middle layer surrounded by two layers of moderate CalR immunoreactivity (Figure 9F, white arrows).

\section{Discussion}

\section{Glutamate Distribution in the G. australis Retina}

Glutamate is the major excitatory neurotransmitter in the retina $[39,40,53-56]$. Our results found glutamate in virtually all retinal neurons of $G$. australis with high levels in photoreceptors, horizontal, amacrine and ganglion cells. A summary of amino acid distribution in the retina of $G$. australis is shown in Figure 10. Glutamate immunoreactivity in the inner retina matched patterns in the northern hemisphere lamprey, $P$. marinus, and several other vertebrates including the goldfish, rat, chicken, cat, monkey and human [22,39,41,54,56-60]. Glutamate was not detected in photoreceptors of postmetamorphic individuals of other lamprey species [22]. This may be due to different photoreceptor morphologies of northern and southern hemisphere lamprey species $[3,30]$. Indeed, glutamate immunoreactivity of photoreceptors of other vertebrates demonstrate considerable diversity [61]. Alternatively, differences in experimental methodology may play a role. This was noted in studies with primate retina, where differences in tissue fixation and manipulation lead to significant changes in amino acid distribution post-mortem [59,60,62,63]. Glutamate immunoreactive photoreceptors in the downstream migrant of $G$. australis also showed a unique distribution with higher glutamate levels near the OPL. This may be due to the uptake of glutamate from the OPL by photoreceptors to deactivate neurotransmission $[64,65]$.

\section{GABA and Glycine Distribution in the G. australis Retina}

The major inhibitory neurotransmitters-GABA and glycine, are commonly associated with lateral retinal elements. GABA is particularly dominant in amacrine cells and shows variable expression in horizontal cells $[41,56,58,59,61,66-68]$. For $G$. australis, strong GABA immunoreactivity was observed in horizontal and amacrine cells at both migratory phases. GABA negative cells in the INL were potentially glycinergic amacrine cells or displaced ganglion cells as GABA is typically absent in ganglion cells $[40,69]$. Similarly, poor GABA immunoreactivity of cells of the IPL suggests this population contains orthotopic ganglion cells or glycinergic displaced or interstitial amacrine cells $[3,22,70]$. Weak GABA immunoreactivity present in putative $G$. australis bipolar cells matched other lamprey species [22], amphibians [66,71,72] and some mammals [69,73-76]. Ascribing a specific bipolar cell type to this population however is difficult as few common features exist between GABAergic bipolar cells in different species. For example, GABA is localized specifically to rod bipolar cells in the primate retina $[59,74]$ whilst in the cat, GABA is present in two OFF cone bipolar cell types [77]. Lack of consistency across species suggests GABA bipolar cells are a species-specific adaptation rather than a fundamental feature of vertebrate visual system evolution.

Glycine is also predominantly found in amacrine cells [61,69,78-82] and to a lesser extent, bipolar cells due to amacrine cell coupling [78,83-85]. We saw highly glycine immunoreactive interplexiform cells in the INL of both upstream and downstream migrating $G$. australis. These cells have been found in teleost fish [86-88], amphibians [89], birds [39] and other lamprey species [22] but not in mammals. Glycine interplexiform cells synapse with horizontal and amacrine cells indicating a role in feedback between the outer and inner retina [90-93]. Glycine immunoreactive cells in the inner INL probably correspond to amacrine cells rather than displaced ganglion cells. Most cells in the IPL were also glycine immunoreactive. In the lamprey $P$. marinus, this population was described as displaced amacrine cells as glycine is rarely detected in vertebrate ganglion cells $[39,59,60,69]$. However, Marc and Jones (2002) showed ganglion cells may contain glycine through gap junctions with other glycinergic cells [94]. The glycine immunoreactive IPL cells were also anatomically similar to interstitial glycinergic amacrine cells observed in the IPL of the goldfish, shark and lizard retinas $[61,70]$. Low levels of GABA immunoreactivity in these cells further support classification of this population as amacrine cells [70]. Finally, glycine observed in the outer retina of the downstream migrant corresponded to typical pattern of Müller cell processes. Indeed, a unique feature of Müller cells of the lamprey retina is a high affinity uptake system to deactivate glycine [88].

\section{Glutamine and Aspartate Distribution in the G. australis Retina}

Glutamine and aspartate play metabolic roles in the retina, maintaining amino acid homeostasis as precursors for glutamate $[95,96]$. Glutamine is mostly found in Müller cells $[39,41,59]$ as well as ganglion cells and horizontal cells in some vertebrates $[28,41,54,56,59,97,98]$. For $G$. australis, glutamine was confined to Müller cells, notable by columns of strong glutamine immunoreactivity in the intercellular space of the outer and inner nuclear layers which closely matched glutamine synthetase labelling. In the horizontal layer, glutamate and GABA immunoreactivity was clearly absent in regions corresponding to Müller cell processes, suggesting that rapid uptake and breakdown of neurotransmitters is a primitive feature of Müller cells [96]. Between migratory phases, glutamine levels were considerably greater in the upstream migrating $G$. australis than the downstream animal. This was closely coupled with increased glutamine synthetase immunoreactivity indicating growth of Müller cells in response to retinal adaptation to the oceanic environment. Alternatively, differences could represent changes in glutamate/glutamine metabolism in glial cells due to changes in neurotransmission between migrants.

Aspartate immunoreactivity also showed dramatic changes isolated to a few cells in the INL of the downstream migrating $G$. australis compared to extensive immunoreactivity in photoreceptors, horizontal cells and the INL in the upstream migrant. In other lamprey species, aspartate immunoreactivity was absent in the larval stages but present in putative ganglion cells, amacrine cells and horizontal cells in the adult animal [22]. Aspartate also co-localized with glutamate and GABA in some horizontal cell 


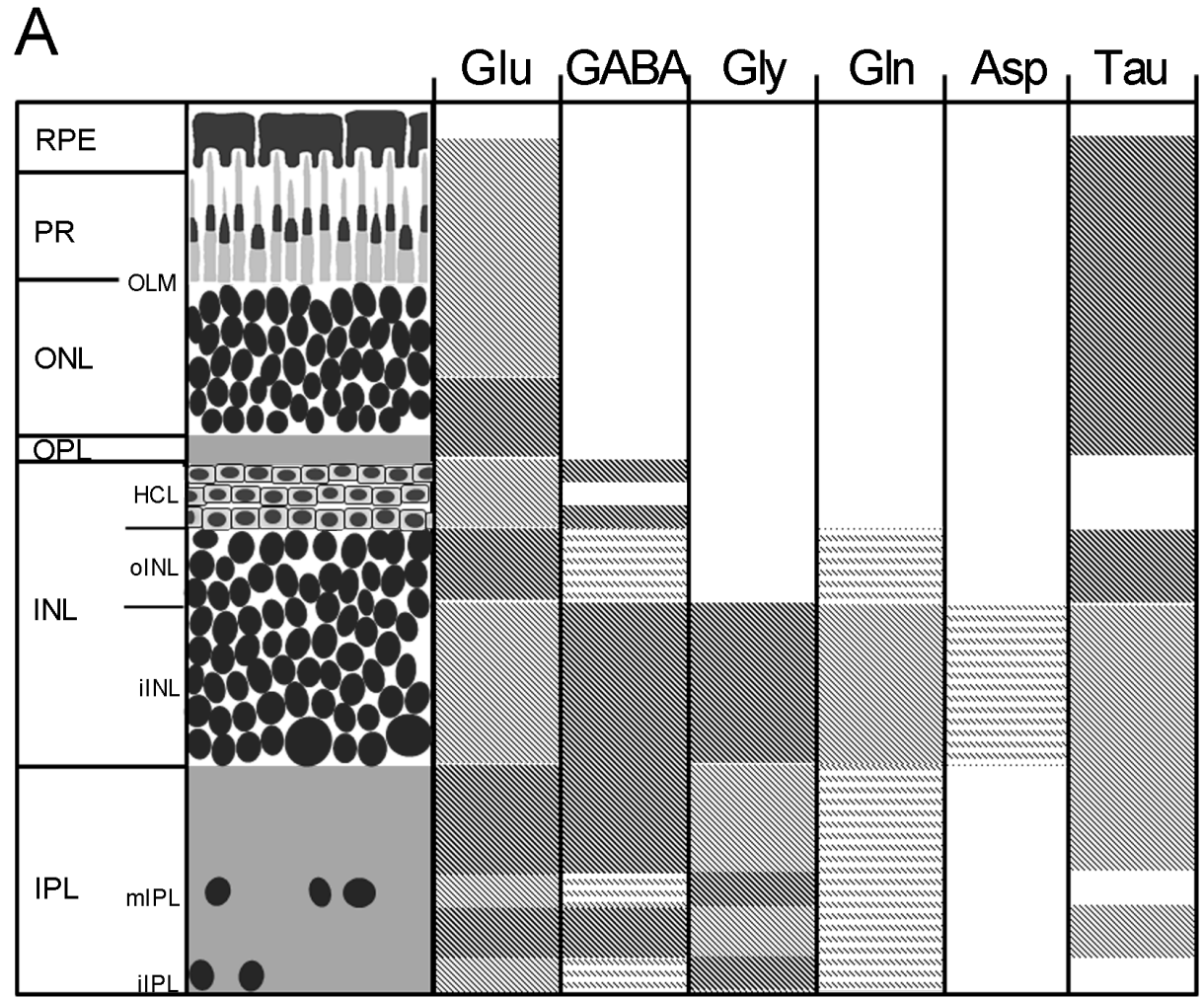

Downstream G. australis

B

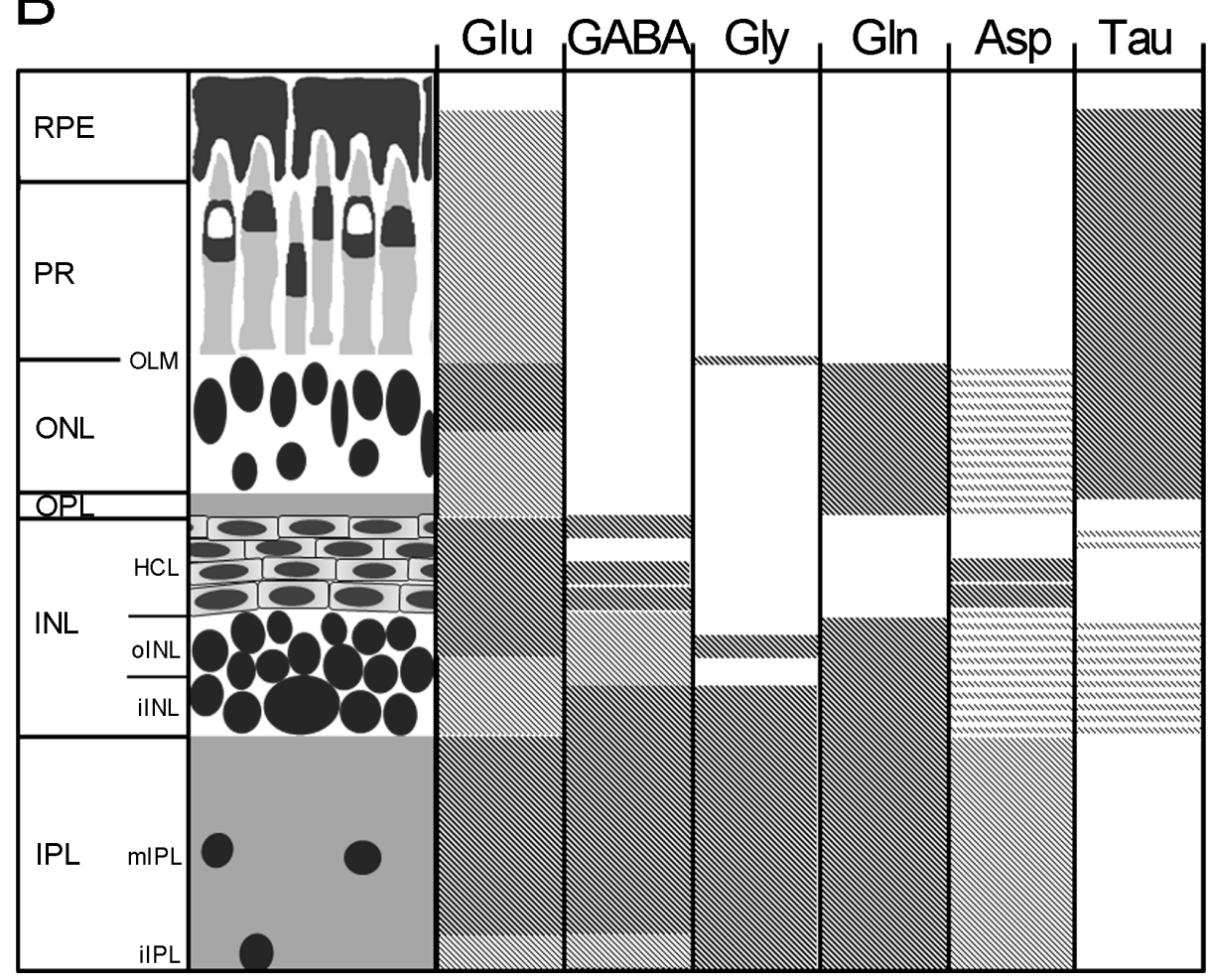

Upstream G. australis 
Figure 10. Schematic of amino acid distribution in the retina of G. australis. Schematic of the A: downstream migrant and B: upstream migrant retinas and their relative amino acid distribution. Drawings on the left indicate the retinal organisation and the degree of shading indicates the average intensity of labelling seen for that amino acid relative to labelling in the rest of the retina. Abbreviations - Glutamate (Glu), $\gamma$ aminobuytric acid (GABA), glycine (Gly), Glutamine (Gln), Aspartate (Asp), Taurine (Tau). All other abbreviations are as in Figure 1.

doi:10.1371/journal.pone.0058406.g010

layers like some horizontal cell sub-populations in the chicken, peccary and lizard retinas [39,56,99]. Expansion of aspartate to the outer retina in the upstream migrant may reflect the need for large pools of neurotransmitter precursor to accommodate the metabolic requirements of the larger photoreceptors and horizontal cells [30]. Indeed, increased aspartate immunoreactivity in the chicken retina subjected to anoxic conditions indicates the sensitivity of this amino acid to the metabolic state of the retina $[39,100]$.

\section{Taurine Distribution in the G. australis Retina}

Taurine has been implicated in osmoregulation, photoprotection, development and apoptosis of retinal neurons [41,101-103]. Taurine was abundant in the $G$. australis retina, particularly in photoreceptors. Extensive taurine distribution is also present in the retinas of goldfish, cat, lizard, shark, monkey and rat supporting its role in fundamental cellular functions $[41,59,61,104]$. Taurine immunoreactivity was also conserved between migratory phases except in Müller cells where taurine immunoreactive cell processes and endfeet were not visible in the upstream migrant. The South African clawed frog also displays little taurine labelling within Müller cells suggesting a possible link between metamorphosis and taurine immunoreactivity of glial cells [61].

\section{Amino Acid Neurochemistry and Retinal Anatomy during G. australis Migration}

The anatomical changes which occur between the retinas of the downstream and upstream migrants of $G$. australis have been noted in several studies $[3,30,32,38]$. Collin et al. (2003) showed that photoreceptors of the upstream migrant of $G$. australis are almost three times larger than equivalent photoreceptor types in the downstream migrant [30]. Additionally, peak spectral sensitivity of the cone-like photoreceptor $\mathrm{C} 2$, shifts in the upstream migrant of G. australis as the yellow myeloid pigment in the outer segment is replaced by a large unpigmented ellipsosome [3,30]. Comparable changes are described for the retina of $P$. marinus [17] and metamorphosing individuals of fish and amphibian species which migrate between fresh water and oceanic environments [105,106]. For example, upstream migrants of the European eel Anguilla anguilla show increased eye size, increased photoreceptor size compared to its downstream migrating counterpart [105]. Current theories point to increased eye size and photoreceptor changes in the lamprey as a response to selective pressures whereby animals in the ocean adopt retinal features which support scotopic vision to avoid avian predators at the water surface $[3,30]$. This study now shows that Müller cells morphology is also altered in the lamprey, with the expansion of Müller cells in the upstream migrant of $G$. australis. Retinal amino acid neurochemistry also changes, particularly for glutamine and aspartate which are increased in the Müller cells of the upstream migrant (Figure 10). Altered Müller cell morphology and amino acids associated with glutamate production is possibly a response to the higher metabolic demands of the larger, reorganised upstream migrant retina. Thus, tight coupling of neuron activity and supporting glia is a feature of the early vertebrate retina.

\section{Cation Channel Permeability}

Basal cation channel permeability of AGB was observed mainly among photoreceptors. Longer incubation times resulted in permeability into inner retinal neurons corresponding to patterns in the rabbit, where bipolar, horizontal, amacrine and some ganglion cells were labelled after a 20 min AGB incubation and the rat, where numerous inner retinal neurons were labelled after a 30 min AGB incubation [107,108]. High levels of AGB were seen in all $G$. australis photoreceptor types. This is likely explained by the presence of only cone-like photoreceptors in the retina of $G$. australis as AGB permeability is thought to be restricted to cones through non-specific cation channels that are not modified with classic cation pharmaceuticals [45]. AGB permeability was similar between upstream and downstream migrating $G$. australis across the incubation time course. Previous studies in jawed vertebrates indicate that AGB enters cells through non-selective ion channels gated by ionotropic glutamate receptors [45]. Thus, identical AGB profiles coupled with similarities in glutamate immunoreactivity indicate that glutamate signalling does not change as the animal matures.

\section{Calcium Binding Protein Distribution}

Recoverin immunoreactivity was confined to photoreceptors, corresponding to patterns observed in other species of lamprey [16] and jawed gnathostomatous vertebrates [109] and suggesting that this protein is highly conserved in the vertebrate visual system. CalB was evident in horizontal cells and amacrine and/or ganglion cells whilst CalR was apparent in bipolar, horizontal, amacrine and ganglion cells. Few differences were observed in CalB and CalR immunoreactivity between the upstream and downstream migrants. CalR negative cells, present in the mid-IPL of the retina of downstream migrant $G$. australis, appeared to be lost in the upstream migrant although this was possibly a product of the decreased cell density associated with an increase in eye size in the postmetamophic lamprey [17]. CalB and CalR immunoreactivity matched that of other lamprey species (Petromyzon marinus, Lampetra fluviatilis) suggesting conservation across species $[18,19]$. Although some discrepancies are evident (i.e. horizontal cells of $L$. fluviatilis are CalB immunonegative), these differences probably reflect acquired species-specific variations rather than stages in evolutionary development. Unique to $G$. australis was the presence of CalB in photoreceptors. Although absent in other lampreys, CalB is present specifically in the cones of jawed vertebrates including pig, sheep, chick, cat and salamander [110]. Anatomical and functional data suggests that all five photoreceptor types in $G$. australis are cone-like, whilst those of other lamprey species are less defined, which may explain the discrepancies in CalB immunoreactivity [3,26,27]. Also interesting were striations of CalR immunoreactivity in the $G$. australis IPL. ChAT and serotonin immunoreactive striations in the IPL have also been observed $[21,24]$.

\section{Conclusion}

We found the distribution of key amino acid neurotransmitters, including glutamate, GABA and glycine were conserved throughout different phases of the lamprey lifecycle. Functional analysis of glutamate channels with AGB also suggests amino acid signalling is a plesiomorphic feature of the vertebrate retina. Calcium protein 
cell markers including recoverin, CalB and CalR were highly conserved supporting an essential role for calcium in the retina. On the other hand, increase levels of neurotransmitter precursors, glutamine and aspartate were observed between the two migrant phases suggesting alterations in the $G$. australis metabolic requirements during migration. This was supported by glutamine synthetase labelling, which demonstrated extensive changes in Müller cells between downstream and upstream migrants. Overall, this suggests retinal anatomical changes associated with adaptation of the $G$. australis retina to ocean environments is coupled with changes in metabolic elements including supporting glia and amino acids involved in glutamate production.

\section{Supporting Information}

\section{Figure S1 Distribution of protein kinase C- $\alpha(P K G \alpha)$ in} the retina of $\boldsymbol{G}$. australis. $\mathrm{PKC} \alpha$ immunoreactivity in the $\mathbf{A}$ :

\section{References}

1. Hardisty MW (1982) Lampreys and hagfishes: analysis of cyclostome relationships. In: Hardisty MW, Potter IC, editors. The Biology of Lampreys London: Academic Press. pp. 165-259.

2. Gill HS, Renaud CB, Chapleau F, Mayden RL, Potter IC (2003) Phylogeny of Living Parasitic Lampreys (Petromyzontiformes) Based on Morphological Data. The American Society of Ichthyologists and Herpetologists.

3. Collin SP, Potter IC, Braekevelt CR (1999) The ocular morphology of the southern hemisphere lamprey geotria australis gray, with special reference to optical specialisations and the characterisation and phylogeny of photoreceptor types. Brain, behavior and evolution 54: 96-118.

4. Collin SP, Pottert IC (2000) The ocular morphology of the southern hemisphere lamprey Mordacia mordax Richardson with special reference to a single class of photoreceptor and a retinal tapetum. Brain, behavior and evolution 55: 120-138.

5. Holmberg K (1978) Light-and electron-microscopic investigation of the optic nerve fiber layer in the river lamprey (Lampetra fluviatilis). Vision research 18: $1313-1320$.

6. Gustafsson OSE, Collin SP, Kröger RHH (2008) Early evolution of multifocal optics for well-focused colour vision in vertebrates. Journal of Experimental Biology 211: 1559-1564.

7. Collin SP, Fritzsch B (1993) Observations on the shape of the lens in the eye of the silver lamprey, Ichthyomyzon unicuspis. Canadian Journal of Zoology 71: $34-41$.

8. Duke-Elder S (1958) System of Ophthalmology 1: The Eye in Evolution St Louis: C.V. Mosby.

9. Dickson DH, Graves DA (1981) The ultrastructure and development of the eye. In: Hardisty MW, Potter IC, editors. The biology of lampreys. London: Academic Press. pp. 43-94.

10. Rubinson K (1990) The developing visual system and metamorphosis in the lamprey. Journal of neurobiology 21: 1123-1135.

11. Rubinson K, Cain H (1989) Neural differentiation in the retina of the larval sea lamprey (Petromyzon marinus). Visual neuroscience 3: 241-248.

12. Fritzsch B, Collin SP (1990) Dendritic distribution of two populations of ganglion cells and the retinopetal fibers in the retina of the silver lamprey (Ichthyomyzon unicuspis). Visual neuroscience 4: 533-545.

13. Dalil N, Reperant J, Kenigfest N, Vesselkin N, Versaux-Botteri C, et al. (1990) Typology and distribution of ganglion cells in the retina of lamprey (Lampetra fluviatilis)]. C R Acad Sci III 311: 403-410.

14. Muradov H, Kerov V, Boyd KK, Artemyev NO (2008) Unique transducins expressed in long and short photoreceptors of lamprey Petromyzon marinus. Vision research 48: 2302-2308.

15. Muradov H, Boyd KK, Kerov V, Artemyev NO (2007) PDE6 in lamprey Petromyzon marinus: implications for the evolution of the visual effector in vertebrates. Biochemistry 46: 9992-10000.

16. Dalil-Thiney N, Bastianelli E, Pochet R, Reperant J, Versaux-Botteri C (1998) Recoverin and hippocalcin distribution in the lamprey (Lampreta fluviatilis) retina. Neuroscience letters 247: 163-166.

17. Wald G (1957) The metamorphosis of visual systems in the sea lamprey. The Journal of general physiology 40: 901-914.

18. Villar-Cheda B, Abalo XM, Anadon R, Rodicio MC (2006) Calbindin and calretinin immunoreactivity in the retina of adult and larval sea lamprey. Brain research 1068: 118-130

19. Dalil-Thiney N, Pochet R, Versaux-Botteri C, Vesselkin N, Reperant J, et al. (1994) Immunohistochemical localization of calbindin-D28K and calretinin in the lamprey retina. The Journal of comparative neurology 340: 140-147.

20. Wasowicz M, Dalil-Thiney N, Vesselkin N, Reperant J, Versaux-Botteri C (1993) [mmunoreactivity to glial fibrillary acidic protein (GFAP) in the retina of the lamprey Lampetra fluviatilis]. C R Acad Sci III 316: 455-458. downstream (DS) migrating and B: upstream (US) migrating $G$. australis. Abbreviations are as in Figure 2. Scale bar is $50 \mu \mathrm{m}$. (TIF)

\section{Acknowledgments}

We would like to thank Howard Gill for assistance in capturing the animals. We would like to thank Dr Robert E. Marc for his kind donation of the amino acid antibodies.

\section{Author Contributions}

Conceived and designed the experiments: SPC DMH ICP MK. Performed the experiments: SPC SR MLA MK. Analyzed the data: LNS YZ SPC MK. Contributed reagents/materials/analysis tools: SPC MLA DMH ICP MK. Wrote the paper: LNS.

21. Pombal MA, Abalo XM, Rodicio M, Anadon R, Gonzalez A, et al. (2003) Choline acetyltransferase-immunoreactive neurons in the retina of adult and developing lampreys. Brain research 993: 154-163.

22. Villar-Cervino V, Abalo XM, Villar-Cheda B, Melendez-Ferro M, PerezCostas E, et al. (2006) Presence of glutamate, glycine, and gammaaminobutyric acid in the retina of the larval sea lamprey: comparative immunohistochemical study of classical neurotransmitters in larval and postmetamorphic retinas. The Journal of comparative neurology 499: 810-827.

23. Dalil-Thiney N, Versaux-Botteri C, Nguyen-Legros J (1996) Electron microscopic demonstration of tyrosine hydroxylase-immunoreactive interplexiform cells in the lamprey retina. Neuroscience letters 207: 159-162.

24. Versaux-Botteri C, Dalil N, Kenigfest N, Reperant J, Vesselkin N, et al. (1991) Immunohistochemical localization of retinal serotonin cells in the lamprey (Lampetra fluviatilis). Visual neuroscience 7: 171-177.

25. Renaud CB (1997) Conservation status of Northern Hemisphere lampreys (Petromyzontidae). Journal of Applied Ichthyology 13: 143-148.

26. Crescitelli $\mathrm{F}$ (1956) The nature of the lamprey visual pigment. The Journal of general physiology 39: 423-435.

27. Harosi FI, Kleinschmidt J (1993) Visual pigments in the sea lamprey, Petromyzon marinus. Visual neuroscience 10: 711-715.

28. Potter IC (1980) The Petromyzoniformes with Particular Reference to Paired Species. Canadian Journal of Fisheries and Aquatic Sciences 37: 1595-1615.

29. Potter IC, Strahan R (1968) The taxonomy of the Lampreys Geotria and Mordacia and their distribution in Australia. Proceedings of the Linnean Society of London 179: 229-240.

30. Collin SP, Hart NS, Shand J, Potter IC (2003) Morphology and spectral absorption characteristics of retinal photoreceptors in the southern hemisphere lamprey (Geotria australis). Visual neuroscience 20: 119-130.

31. Collin SP, Trezise AEO (2004) The origins of colour vision in vertebrates. Clinical and Experimental Optometry 87: 217-223.

32. Davies WL, Cowing JA, Carvalho LS, Potter IC, Trezise AE, et al. (2007) Functional characterization, tuning, and regulation of visual pigment gene expression in an anadromous lamprey. The FASEB journal : official publication of the Federation of American Societies for Experimental Biology 21: $2713-2724$

33. Davies WI, Collin SP, Hunt DM (2012) Molecular ecology and adaptation of visual photopigments in craniates. Mol Ecol 21: 3121-3158.

34. Collin SP, Knight MA, Davies WL, Potter IC, Hunt DM, et al. (2003) Ancient colour vision: multiple opsin genes in the ancestral vertebrates. Curr Biol 13: R864-865.

35. Davies WL, Collin SP, Hunt DM (2009) Adaptive gene loss reflects differences in the visual ecology of basal vertebrates. Mol Biol Evol 26: 1803-1809.

36. Potter IC, Prince PA, Croxall JP (1979) Data on the adult marine and migratory phases in the life cycle of the southern hemisphere lamprey, Geotria australis Gray. Environmental Biology of Fishes 4: 65-69.

37. Potter IC, Hilliard RW, Bird DJ, Macey DJ (1983) Quantitative data on morphology and organ weights during the protracted spawning-run period of the Southern Hemisphere lamprey Geotria australis. Journal of Zoology 200: $1-20$.

38. Collin SP, Hart NS, Wallace KM, Shand J, Potter IC (2004) Vision in the southern hemisphere lamprey Mordacia mordax: spatial distribution, spectral absorption characteristics, and optical sensitivity of a single class of retinal photoreceptor. Visual neuroscience 21: 765-773.

39. Kalloniatis M, Fletcher EL (1993) Immunocytochemical localization of the amino acid neurotransmitters in the chicken retina. The Journal of comparative neurology 336: 174-193.

40. Marc RE, Liu WL, Kalloniatis M, Raiguel SF, van Haesendonck E (1990) Patterns of glutamate immunoreactivity in the goldfish retina. The Journal of neuroscience 10: 4006-4034. 
41. Marc RE, Murry RF, Basinger SF (1995) Pattern recognition of amino acid signatures in retinal neurons. The Journal of neuroscience 15: 5106-5129.

42. Sun D, Rait JL, Kalloniatis M (2003) Inner retinal neurons display differential responses to N-methyl-D-aspartate receptor activation. The Journal of comparative neurology 465: 38-56.

43. Edwards FA, Konnerth A, Sakmann B, Takahashi T (1989) A thin slice preparation for patch clamp recordings from neurones of the mammalian central nervous system. Pflugers Archiv : European journal of physiology 414: 600-612.

44. Marc RE, Jones BW, Anderson JR, Kinard K, Marshak DW, et al. (2007) Neural reprogramming in retinal degeneration. Investigative ophthalmology \& visual science 48: 3364-3371.

45. Marc RE (1999) Mapping glutamatergic drive in the vertebrate retina with a channel-permeant organic cation. The Journal of comparative neurology 407: $47-64$

46. Sun D, Kalloniatis M (2006) Mapping glutamate responses in immunocytochemically identified neurons of the mouse retina. The Journal of comparative neurology 494: 686-703.

47. Sun D, Vingrys AJ, Kalloniatis M (2007) Metabolic and functional profiling of the normal rat retina. The Journal of comparative neurology 505: 92-113.

48. Yan XX, Wiechmann AF (1997) Early expression of recoverin in a unique population of neurons in the human retina. Anat Embryol (Berl) 195: 51-63.

49. Einarson L (1932) A Method for Progressive Selective Staining of Nissl and Nuclear Substance in Nerve Cells. American Journal of Pathology 8: 295-308 295.

50. Kalloniatis M, Napper GA (2002) Retinal neurochemical changes following application of glutamate as a metablolic substrate. Clinical \& experimental optometry : journal of the Australian Optometrical Association 85: 27-36.

51. Marc RE (1999) Kainate activation of horizontal, bipolar, amacrine, and ganglion cells in the rabbit retina. The Journal of comparative neurology 407 : 65-76.

52. Picco C, Menini A (1993) The permeability of the cGMP-activated channel to organic cations in retinal rods of the tiger salamander. The Journal of physiology 460: 741-758.

53. Ehinger B, Ottersen OP, Storm-Mathisen J, Dowling JE (1988) Bipolar cells in the turtle retina are strongly immunoreactive for glutamate. Proceedings of the National Academy of Sciences of the United States of America 85: 8321-8325.

54. Fletcher EL, Kalloniatis M (1997) Localisation of amino acid neurotransmitters during postnatal development of the rat retina. The Journal of comparative neurology 380: 449-471.

55. Pow DV, Crook DK, Wong RO (1994) Early appearance and transient expression of putative amino acid neurotransmitters and related molecules in the developing rabbit retina: an immunocytochemical study. Visual neuroscience 11: 1115-1134.

56. Kalloniatis M, Tomisich G (1999) Amino acid neurochemistry of the vertebrate retina. Progress in retinal and eye research 18: 811-866.

57. Marc RE, Murry RF, Fisher SK, Linberg KA, Lewis GP (1998) Amino acid signatures in the detached cat retina. Investigative ophthalmology \& visual science 39: 1694-1702.

58. Marc RE, Murry RF, Fisher SK, Linberg KA, Lewis GP, et al. (1998) Amino acid signatures in the normal cat retina. Investigative ophthalmology \& visual science 39: 1685-1693.

59. Kalloniatis M, Marc RE, Murry RF (1996) Amino acid signatures in the primate retina. The Journal of neuroscience 16: 6807-6829.

60. Davanger S, Ottersen OP, Storm-Mathisen J (1991) Glutamate, GABA, and glycine in the human retina: an immunocytochemical investigation. The Journal of comparative neurology 311: 483-494.

61. Kalloniatis M, Loh CS, Acosta ML, Tomisich G, Zhu Y, et al. Retinal amino acid neurochemistry in health and disease. Clinical and Experimental Optometry doi: 10.1111/CXO.12015.

62. Crooks J, Kolb H (1992) Localization of GABA, glycine, glutamate and tyrosine hydroxylase in the human retina. The Journal of comparative neurology 315: 287-302.

63. Martin PR, Grünert U (1992) Spatial density and immunoreactivity of bipolar cells in the macaque monkey retina. The Journal of comparative neurology 323: 269-287.

64. Marc RE, Lam DM (1981) Uptake of aspartic and glutamic acid by photoreceptors in goldfish retina. Proceedings of the National Academy of Sciences of the United States of America 78: 7185-7189.

65. Haverkamp S, Grünert U, Wässle H (2000) The cone pedicle, a complex synapse in the retina. Neuron 27: 85-95.

66. Mosinger JL, Yazulla S, Studholme KM (1986) GABA-like immunoreactivity in the vertebrate retina: a species comparison. Experimental eye research 42: 631-644.

67. Marc RE (1992) Structural organization of GABAergic circuitry in ectotherm retinas. Prog Brain Res 90: 61-92.

68. Osborne NN, Patel S, Beaton DW, Neuhoff V (1986) GABA neurones in retinas of different species and their postnatal development in situ and in culture in the rabbit retina. Cell and tissue research 243: 117-123.

69. Fletcher EL, Kalloniatis M (1996) Neurochemical architecture of the normal and degenerating rat retina. The Journal of comparative neurology 376: $343-$ 360 .
70. Yazulla S, Studholme KM (1990) Multiple subtypes of glycine-immunoreactive neurons in the goldfish retina: single- and double-label studies. Visual neuroscience 4: 299-309.

71. Yang CY, Yazulla S (1994) Glutamate-, GABA-, and GAD-immunoreactivities co-localize in bipolar cells of tiger salamander retina. Visual neuroscience 11: 1193-1203.

72. Yang CY (1998) gamma-aminobutyric acid transporter-mediated current from bipolar cells in tiger salamander retinal slices. Vision research 38: 2521-2526.

73. Wässle H, Chun MH (1989) GABA-like immunoreactivity in the cat retina: light microscopy. The Journal of comparative neurology 279: 43-54.

74. Grünert U, Wässle H (1990) GABA-like immunoreactivity in the macaque monkey retina: a light and electron microscopic study. The Journal of comparative neurology 297: 509-524.

75. Pourcho RG, Owczarzak MT (1989) Distribution of GABA immunoreactivity in the cat retina: a light- and electron-microscopic study. Visual neuroscience 2: $425-435$.

76. Agardh E, Ehinger B, Wu JY (1987) GABA and GAD-like immunoreactivity in the primate retina. Histochemistry 86: 485-490.

77. Kao YH, Lassova L, Bar-Yehuda T, Edwards RH, Sterling P, et al. (2004) Evidence that certain retinal bipolar cells use both glutamate and GABA. The Journal of comparative neurology 478: 207-218.

78. Marc RE (1989) The role of glycine in the mammalian retina. In: Osborne N, Chader G, editors. Progress in retinal research. London: Pergamon. pp. 67107.

79. Marc RE, Liu WL (1985) (3H) glycine-accumulating neurons of the human retina. The Journal of comparative neurology 232: 241-260.

80. Pourcho RG, Goebel DJ (1985) Immunocytochemical demonstration of glycine in retina. Brain research 348: 339-342.

81. Pourcho RG, Goebel DJ (1985) A combined Golgi and autoradiographic study of $(3 \mathrm{H})$ glycine-accumulating amacrine cells in the cat retina. The Journal of comparative neurology 233: 473-480.

82. Hendrickson AE, Koontz MA, Pourcho RG, Sarthy PV, Goebel DJ (1988) Localization of glycine-containing neurons in the Macaca monkey retina. The Journal of comparative neurology 273: 473-487.

83. Pourcho RG, Goebel DJ (1987) A combined Golgi and autoradiographic study of $3 \mathrm{H}$-glycine-accumulating cone bipolar cells in the cat retina. The Journal of neuroscience 7: 1178-1188.

84. Trexler EB, Li W, Mills SL, Massey SC (2001) Coupling from AII amacrine cells to $\mathrm{ON}$ cone bipolar cells is bidirectional. The Journal of comparative neurology 437: 408-422.

85. Vaney DI, Nelson JC, Pow DV (1998) Neurotransmitter coupling through gap junctions in the retina. The Journal of neuroscience 18: 10594-10602.

86. Kalloniatis M, Marc RE (1990) Interplexiform cells of the goldfish retina. The Journal of comparative neurology 297: 340-358.

87. Marc RE (1982) Spatial organization of neurochemically classified interneurons of the goldfish retina-I. Local patterns. Vision research 22: 589-608.

88. Marc RE (1985) The role of glycine in retinal circuitry. In: Morgan WW, editor. Retinal Transmitters and Modulators: Models for the Brain. Boca Raton, FL: CRC Press. pp. 119-158.

89. Marc RE (1986) Neurochemical stratification in the inner plexiform layer of the vertebrate retina. Vision research 26: 223-238.

90. Kolb H, West RW (1977) Synaptic connections of the interplexiform cell in the retina of the cat. Journal of neurocytology 6: 155-170.

91. Dowling JE, Ehinger B (1978) The interplexiform cell system. I. Synapses of the dopaminergic neurons of the goldfish retina. Proceedings of the Royal Society of London Series B, Containing papers of a Biological character Royal Society 201: 7-26.

92. Marc RE, Liu WL (1984) Horizontal cell synapses onto glycine-accumulating interplexiform cells. Nature 312: 266-269.

93. Jiang Z, Shen W (2010) Role of neurotransmitter receptors in mediating lightevoked responses in retinal interplexiform cells. Journal of neurophysiology 103: 924-933.

94. Marc RE, Jones BW (2002) Molecular phenotyping of retinal ganglion cells. The Journal of neuroscience 22: 413-427.

95. Voaden MJ, Lake N, Marshall J, Morjaria B (1978) The utilization of glutamine by the retina: an autoradiographic and metabolic study. Journal of neurochemistry 31: 1069-1076.

96. Hertz L (1979) Functional interactions between neurons and astrocytes I. Turnover and metabolism of putative amino acid transmitters. Progress in neurobiology 13: 277-323.

97. Kalloniatis M, Tomisich G, Marc RE (1994) Neurochemical signatures revealed by glutamine labeling in the chicken retina. Visual neuroscience 11 : 793-804.

98. Lugo-Garcia N, Blanco RE (1991) Localization of GAD- and GABA-like immunoreactivity in ground squirrel retina: retrograde labeling demonstrates GAD-positive ganglion cells. Brain research 564: 19-26.

99. Sherry DM, Ulshafer RJ (1992) Neurotransmitter-specific identification and characterization of neurons in the all-cone retina of Anolis carolinensis. II: Glutamate and aspartate. Visual neuroscience 9: 313-323.

100. Yaqub A, Eldred WD (1991) Localization of aspartate-like immunoreactivity in the retina of the turtle (Pseudemys scripta). The Journal of comparative neurology 312: 584-598.

101. Lombardini JB (1991) Taurine: retinal function. Brain Res Brain Res Rev 16: 151-169. 
102. Warskulat U, Borsch E, Reinehr R, Heller-Stilb B, Roth C, et al. (2007) Taurine deficiency and apoptosis: findings from the taurine transporter knockout mouse. Archives of biochemistry and biophysics 462: 202-209.

103. Warskulat U, Heller-Stilb B, Oermann E, Zilles K, Haas H, et al. (2007) Phenotype of the taurine transporter knockout mouse. Methods Enzymol 428: $439-458$

104. Kuriyama K, Sasamoto K, Kimura H (1990) A developmental and functional study on taurine-like immunoreactivity in the rat retina. Progress in clinical and biological research 351: 29-36.

105. Carlisle DB, Denton EJ (1959) On the metamorphosis of the visual pigments of Anguilla anguilla (L.). Journal of the Marine Biological Association of the United Kingdom 38: 97-102.
106. Wald G (1946) The metamorphosis of visual system in Amphibia. Biol Bull 91: 239.

107. Kalloniatis M, Tomisich G, Wellard JW, Foster LE (2002) Mapping photoreceptor and postreceptoral labelling patterns using a channel permeable probe (agmatine) during development in the normal and RCS rat retina. Visual neuroscience 19: 61-70.

108. Marc RE, Kalloniatis M, Jones BW (2005) Excitation mapping with the organic cation AGB2+. Vision research 45: 3454-3468.

109. Chen C-KJ (2003) Recoverin And Rhodopsin Kinase, Photoreceptors and Calcium. In: Baehr W, Palczewski K, editors: Springer US. pp. 101-107.

110. Pasteels B, Rogers J, Blachier F, Pochet R (1990) Calbindin and calretinin localization in retina from different species. Visual neuroscience 5: 1-16. 